\title{
The role of mixing in controlling resource availability and phytoplankton community composition
}

\author{
Marina Villamaña $^{\mathrm{a}, *}$, Emilio Marañón ${ }^{\mathrm{a}}$, Pedro Cermeño ${ }^{\mathrm{b}}$, Marta Estrada ${ }^{\mathrm{b}}$, \\ Bieito Fernández-Castro ${ }^{\mathrm{c}}$, Francisco G. Figueiras ${ }^{\mathrm{d}}$, Mikel Latasa ${ }^{\mathrm{e}}$, Jose Luis Otero-Ferrer ${ }^{\mathrm{a}}$, \\ Beatriz Reguera ${ }^{\mathrm{f}}$, Beatriz Mouriño-Carballido ${ }^{\mathrm{a}}$ \\ ${ }^{a}$ Departamento de Ecoloxía e Bioloxía Animal, Universidade de Vigo, Campus As Lagoas-Marcosende, 36310 Vigo (Pontevedra), Spain \\ ${ }^{\mathrm{b}}$ Institut de Ciències del Mar, Consejo Superior de Investigaciones Científicas, Passeig Maritim de la Barceloneta, 37-49, E-08003 Barcelona, Spain \\ ${ }^{\mathrm{c}}$ École Polytechnique Fédérale de Lausanne, Lausanne, Switzerland \\ ${ }^{\mathrm{d}}$ Instituto de Investigacións Mariñas, Consejo Superior de Investigaciones Científicas, Eduardo Cabello 6, 36208 Vigo (Pontevedra), Spain

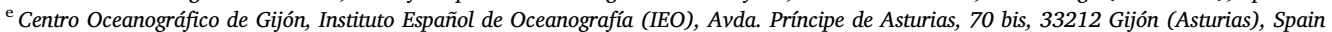 \\ ${ }^{\mathrm{f}}$ Centro Oceanográfico de Vigo, Instituto Español de Oceanografia (IEO), Subida a Radio Faro 50, 36390 Vigo (Pontevedra), Spain
}

\begin{abstract}
A B S T R A C T
We investigate the role of mixing, through its effect on nutrient and light availability, as a driver of phytoplankton community composition in the context of Margalef's mandala. Data on microstructure turbulence, irradiance, new nitrogen supply and phytoplankton composition were collected at 102 stations in three contrasting marine environments: the Galician coastal upwelling system of the northwest Iberian Peninsula, the northwestern Mediterranean, and the tropical and subtropical Atlantic, Pacific and Indian oceans. Photosynthetic pigments concentration and microscopic analysis allowed us to investigate the contribution of diatoms, dinoflagellates, pico- and nanoeukaryotes, and cyanobacteria to the phytoplankton community. Simple linear regression was used to assess the role of environmental factors on community composition, and environmental overlap among different phytoplankton groups was computed using nonparametric kernel density functions. Mixing and new nitrogen supply played an important role in controlling the phytoplankton community structure. At lower values of mixing and new nitrogen supply cyanobacteria dominated, pico- and nanoeukaryotes were dominant across a wide range of environmental conditions, and finally enhanced new nitrogen supply was favourable for diatoms and dinoflagellates. Dinoflagellates were prevalent at intermediate mixing levels, whereas diatoms spread across a wider range of mixing conditions. Occasional instances of enhanced diatom biomass were found under low mixing, associated with the high abundance of Hemiaulus hauckii co-occurring with high $\mathrm{N}_{2}$ fixation in subtropical regions, and with the formation of thin layers in the Galician coastal upwelling. Our results verify the Margalef's mandala for the whole phytoplankton community, emphasizing the need to consider nutrient supply, rather than nutrient concentration, as an indicator of nutrient availability.
\end{abstract}

\section{Introduction}

Marine phytoplankton are responsible for nearly half of Earth's primary production (Field et al., 1998), constitute the base of most marine food webs, and contribute to regulate the ocean-atmosphere $\mathrm{CO}_{2}$ exchange (Falkowski, 2012; Falkowski et al., 1998). Because of their key role in the functioning of aquatic ecosystems and global climate, it is important to understand the factors that control phytoplankton communities. Phytoplankton growth is limited by the availability of light and nutrients, but these variables have opposite vertical distributions in the water column. Thus, photosynthesis in aquatic systems is constrained to where light and nutrients coexist. Since turbulence is the principal physical process involved in dispersing solutes and small particles in the ocean (Thorpe, 2007), it indirectly affects phytoplanktonic organisms by controlling the availability of light and nutrients in the upper layer. For this reason, model formulations aiming to explain the behaviour of individual phytoplankton cells, or collective functional groups, frequently include turbulence as a control factor.

Margalef's mandala (Margalef, 1978) was one of the first approaches to describe the role of turbulence in the selection of different "life-forms" of phytoplankton in a conceptual model. In the original diagram, different phytoplankton groups were placed in an ecological space defined by mixing levels and nutrient concentration. Because the supply of nutrients into the euphotic zone is frequently determined by mixing, species adapted to high nutrient concentrations tend to be adapted, as well, to high mixing levels, and vice versa. The conceptual diagram was broadly divided into four domains, defined by high and low turbulence levels and high and low nutrient concentration (I-IV in Fig. 1). The main sequence of phytoplankton follows a diagonal from upper right (high turbulence-high nutrient) to lower left (low

\footnotetext{
* Corresponding author.

E-mail address: mvillamana@vigo.es (M. Villamaña).
} 


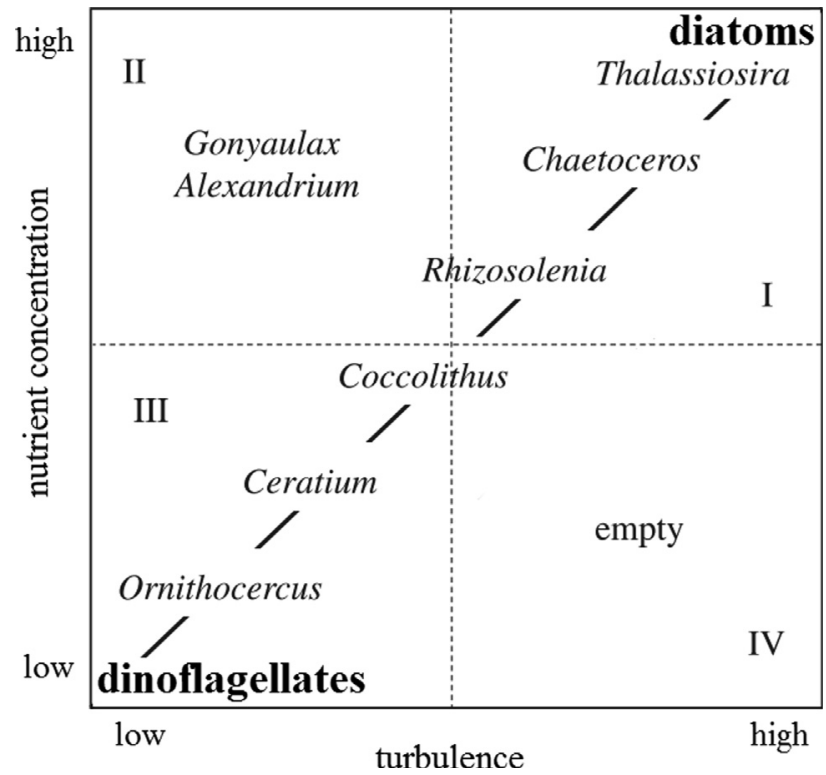

Fig. 1. Adaptation of the Margalef's mandala showing phytoplankton life-forms in an ecological space defined by turbulence and nutrient concentration. I-IV indicates the four domains defined by high and low turbulence levels and nutrient concentration.

turbulence-low nutrient). Diatoms are dominant in turbulent water rich in nutrients (domain I), whereas dinoflagellates dominate in stratified waters where nutrients are scarce (domain III). The anomalous combination of high nutrient concentration with low turbulence (domain II) leads to an alternative route, the red tide sequence, characterized by rounded dinoflagellate swimming species which form harmful algal blooms (e.g., Gonyaulax, Alexandrium). Domain IV is associated with low-nutrient, high-turbulence conditions and was considered void or empty in the original mandala. By considering the average value of the turbulent diffusion coefficient in the top layers of the oceans $\left(0.4 \mathrm{~cm}^{2}\right.$ $\mathrm{s}^{-1}$ ) as the transition limit, derived from indirect estimates at the time, Margalef estimated that diatoms dominate over the range $2-100 \mathrm{~cm}^{2} \mathrm{~s}^{-1}$ and dinoflagellates over $0.02-1 \mathrm{~cm}^{2} \mathrm{~s}^{-1}$. Although not represented in the original diagram, other environmental factors such as grazing or light availability were also discussed by Margalef (1978).

Several conceptual models have revisited Margalef's mandala. Reynolds's Intaglio (Reynolds, 1987) allows the selection of phytoplankton species along a gradient of energy (a combination of mixing depth and irradiance) and nutrient availability. Smayda and Reynolds (2001) found that the Intaglio was better than the mandala in predicting harmful algal blooms (HAB) in coastal waters, because of its ability to distinguish nine different harmful dinoflagellate types and their associated mixing-nutrient habitats (Cullen and MacIntyre, 1998). The most recent conceptual model proposed by Glibert (2016) incorporated twelve dimensions, including nutritional physiology.
One of the main difficulties in verifying these conceptual models in the field is to quantify the variables involved (Estrada and Berdalet, 1996). Due to methodological limitations, turbulence has been historically difficult to measure in the field. A commonly used approach is to conduct laboratory experiments, (Estrada et al., 1988; Guadayol et al., 2009; Peters and Marrasé, 2000; Peters and Redondo, 1997), with the limitation that phytoplankton communities might be exposed to unrealistic levels of turbulence. Another approach is to use different proxies for quantifying turbulence and nutrient supply in the field (Bowman et al., 1981; Cermeño et al., 2008; Irwin et al., 2012; Pearman et al., 2017). Currently, instruments designed to measure the dissipation rate of turbulent kinetic energy and/or thermal variance (Prandke and Stips, 1998; Stevens et al., 1999; Wolk et al., 2002) allow the study of mixing (Machado et al. 2014) and nutrient supply (Fernández-Castro et al., 2015; Mouriño-Carballido et al., 2016; Sharples et al., 2007; Villamaña et al., 2017) as drivers of phytoplankton community structure in the field. Moreover, the original Margalef's mandala was constrained by the sampling procedures of its era (Wyatt, 2014). At the time it was conceived, open ocean observations and time series were rudimentary and not very frequent, and sampling was primarily constrained to the surface (Kemp and Villareal, 2018). The mandala was conceived before it was widely appreciated that autotrophic and heterotrophic picoplankton, mainly supported by regenerated nutrients (the microbial loop), dominate the oligotrophic ocean (Cullen et al., 2002), and considered only microphytoplankton groups. Other processes and features whose importance was still comparatively unappreciated at the time of the mandala's conception include biological nitrogen $\left(\mathrm{N}_{2}\right)$ fixation and the role of diatom-diazotroph symbiosis, phytoplankton thin layers, the effect of iron (Fe) on planktonic productivity and mixotrophy.

Here we investigate the role of mixing, through its effect on the availability of nitrate and light, in the control of phytoplankton community composition. We combine a large data set of microstructure turbulence, irradiance, nitrate concentration and phytoplankton community composition, derived from microscopy and pigment analysis, collected in contrasting marine environments. Our goal is to present an evaluation of Margalef's mandala in the field that considers the whole phytoplankton assemblage, including pico- and nanoeukaryotes and cyanobacteria, and is based on direct measurements, rather than proxies, of new nitrogen supply into the euphotic layer.

\section{Material and methods}

Data were collected at 102 stations located in the tropical and subtropical Atlantic, Pacific and Indian Oceans (T), the northwestern Mediterranean Sea (M), and the Galician coastal upwelling ecosystem (G), between March 2009 and August 2013 (see Table 1 and Fig. 2). One expedition (Malaspina, Dec 2010-Jul 2011) sampled 59 stations, which were mainly located in the tropical and subtropical Atlantic, Indian and Pacific oceans. Three other cruises carried out in the Mediterranean Sea (FAMOSO1 Mar 2009, FAMOSO2 Apr-May 2009, and

Table 1

Details of the data included in this study. Domains considered are tropical and subtropical (T), northwestern Mediterranean (M) and Galician upwelling region (G). The number of stations sampled on each cruise for microstructure turbulence and nitrate concentration (N1), microphytoplankton cell counts (N2), photosynthetic pigments (N3) and light availability (N4) is indicated.

\begin{tabular}{|c|c|c|c|c|c|c|c|c|}
\hline Domain & Region & N1 & N2 & N3 & N4 & Cruise & $\mathrm{R} / \mathrm{V}$ & Date \\
\hline $\mathrm{T}$ & Atlantic, Pacific and Indian Oceans & 59 & 59 & 59 & 52 & MALASPINA & Hespérides & $16 / 12 / 10-10 / 07 / 11$ \\
\hline M & Liguro-Provençal Basin & 4 & 4 & 4 & 4 & FAMOSO I & Sarmiento de Gamboa & $14 / 03 / 09-22 / 03 / 09$ \\
\hline M & Liguro-Provençal Basin & 9 & 9 & 9 & 7 & FAMOSO II & Sarmiento de Gamboa & $30 / 04 / 09-13 / 05 / 09$ \\
\hline M & Liguro-Provençal Basin & 3 & 3 & 3 & 3 & FAMOSO III & Sarmiento de Gamboa & $16 / 09 / 09-20 / 09 / 09$ \\
\hline G & Ría de Vigo & 10 & 10 & - & 8 & DISTRAL-REIMAGE & Mytilus & $14 / 02 / 12-24 / 01 / 13$ \\
\hline G & Rías de Vigo and Pontevedra & 13 & 9 & 6 & 13 & ASIMUTH & Ramón Margalef & $17 / 06 / 13-21 / 06 / 13$ \\
\hline G & Ría de Vigo & 4 & 4 & 3 & 4 & CHAOS & Mytilus & $20 / 08 / 13-27 / 08 / 13$ \\
\hline
\end{tabular}




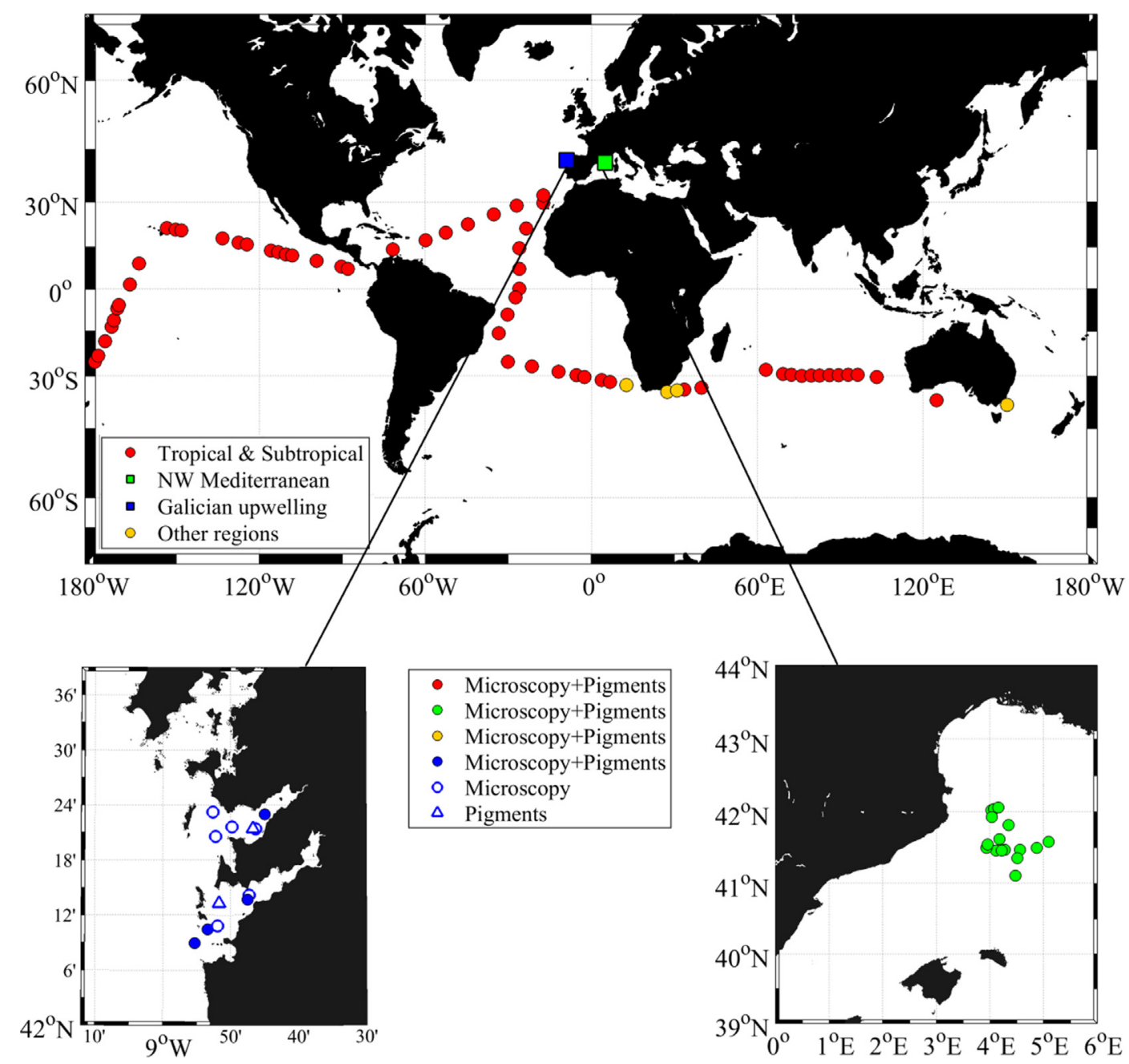

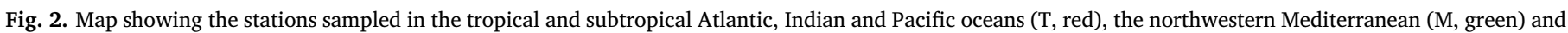

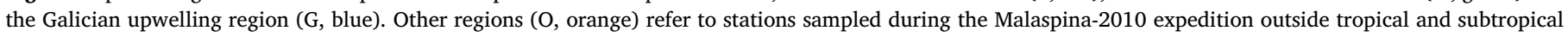

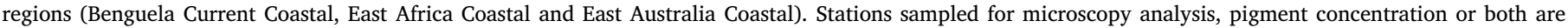
indicated. (For interpretation of the references to color in this figure legend, the reader is referred to the web version of this article.)

FAMOSO3 Sep 2009) sampled 16 stations during three contrasting hydrographic conditions, covering from winter mixing to summer stratification. Finally, 27 stations were visited in the Galician coastal upwelling region (DISTRAL-REIMAGE Feb 2012-Jan 2013; ASIMUTH Jun 2013; and CHAOS Aug 2013). Measurements of microstructure turbulence were carried out in parallel to sampling for the determination of nitrate concentration (102 stations), microphytoplankton community composition (98 stations), photosynthetic pigments concentration (84 stations), and $\mathrm{N}_{2}$ fixation (38 stations). Additional information on the sampling design of these cruises is included in: Estrada et al. (2016, Malaspina); Fernández-Castro et al. (2014, Malaspina); Estrada et al. (2014, FAMOSO); Mouriño-Carballido et al. (2016, FAMOSO); Cermeño et al. (2016, DISTRAL-REIMAGE); Villamaña et al. (2017, CHAOS); Díaz et al., (2019, ASIMUTH).

\subsection{Microstructure turbulence}

Hydrographic properties and turbulent mixing were derived from a microstructure turbulent profiler (Prandke and Stips, 1998) equipped with two microstructure shear sensors (type PNS06), a high-precision Conductivity-Temperature-Depth (CTD) probe, including a fluorescence sensor, and a sensor to measure the horizontal acceleration of the profiler. Microstructure turbulence profiles used for computing nitrate fluxes at each station were always deployed successively. The average number of vertical profiles of dissipation rates of turbulent kinetic energy $(\varepsilon)$ obtained at each station was $3 \pm 1$ in tropical and subtropical regions $(37 \pm 18 \mathrm{~min}), \quad 7 \pm 0$ in the NW Mediterranean $(76 \pm 22 \mathrm{~min})$, and $32 \pm 55$ in the Galician coastal upwelling (79 $\pm 285 \mathrm{~min})$. Turbulence can induce episodic inputs of nutrient supply, which can be easily missed when a low number of profiles are deployed. In the Galician coastal upwelling our dataset included two $25 \mathrm{~h}$ high-frequency samplings carried out in the Ría de Vigo (Galician upwelling region). Turbulence at the interface between upwelled and surface waters was enhanced by 2 orders of magnitude during the ebbs, as the result of the interplay of the bidirectional upwelling circulation and the tidal current shear (Fernández-Castro et al., 2018).

The profiler, which was balanced to have negative buoyancy and a sinking velocity of $\sim 0.4-0.7 \mathrm{~m} \mathrm{~s}^{-1}$, was cast down to a maximum depth of 30-300 m. The frequency of data sampling was $1024 \mathrm{~Hz}$. The sensitivity of the shear sensors was checked after each use. Due to significant turbulence generation close to the ship, only data obtained below a certain depth ( $5 \mathrm{~m}$ for DISTRAL-REIMAGE, ASIMUTH, and CHAOS; and $10 \mathrm{~m}$ for FAMOSO1, FAMOSO2, FAMOSO3 and Malaspina) were considered reliable. Data processing and calculation of dissipation rates of $\varepsilon$ was carried out following the procedure described in Fernández-Castro et al. (2014). The squared Brunt Väisälä frequency $\left(\mathrm{N}^{2}\right)$ was computed from the CTD profiles according to the equation: 
$N^{2}=-\left(\frac{\mathrm{g}}{\rho_{w}}\right)\left(\frac{\partial \rho}{\partial z}\right)\left(\mathrm{s}^{-2}\right)$

where $\mathrm{g}$ is the acceleration due to gravity $\left(9.8 \mathrm{~m} \mathrm{~s}^{-2}\right), \rho_{w}$ is a reference seawater density $\left(1025 \mathrm{~kg} \mathrm{~m}^{-3}\right)$, and $\partial \rho / \partial z$ is the vertical potential density gradient. Vertical diffusivity $\left(K_{z}\right)$ was estimated as:

$K_{z}=\Gamma \frac{\varepsilon}{N^{2}}\left(\mathrm{~m}^{2} \mathrm{~s}^{-1}\right)$

where $\Gamma$ is the mixing efficiency, here considered as 0.2 (Osborn, 1980).

For the stations located in tropical and subtropical regions, vertical diffusivity including mechanical turbulence and the effect of salt fingers was calculated according to St. Laurent and Schmitt (1999) (see details in Fernández-Castro et al. 2015). The K-profile parameterization (KPP) described by Large et al. (1994) was used to compute vertical diffusivity at 14 stations carried out in the Indian Ocean during Malaspina, where measurements of microstructure turbulence were not acquired (see Fernández-Castro et al. (2014)).

\subsection{New nitrogen supply}

Samples for the determination of nitrate $\left(\mathrm{NO}_{3}{ }^{-}\right.$) (or nitrate + nitrite in the case of Malaspina cruises) were collected from Niskin bottles at 3-12 depths in rinsed polyethylene tubes. Samples were immediately analyzed on board (Malaspina) or frozen and stored at $-20^{\circ} \mathrm{C}$ until later analysis on land (the other cruises), in all cases using the methods described by Grasshoff et al. (2007). Nitrate concentration data included in the World Ocean Atlas 2009 (WOA09) database were used in 4 stations sampled during the Malaspina expedition where nitrate concentrations were not available (see Fernández-Castro et al. 2015).

Vertical diffusive fluxes of nitrate were calculated, following Fick's law, as:

$\mathrm{NO}_{3}^{-}$diffusive flux $=\bar{K}_{Z} \Delta \mathrm{NO}_{3}^{-}$

where $\Delta \mathrm{NO}_{3}^{-}$is the nitrate vertical gradient obtained by linear fitting of nitrate concentrations in the nitracline, determined as a region of approximately maximum and constant gradient, and $\bar{K}_{z}$ is the averaged vertical diffusivity in the same depth interval. In the Galician coastal upwelling, nitrate diffusive fluxes were estimated between 10 and $40 \mathrm{~m}$ depth using the same procedure.

In tropical and subtropical regions sampled during Malaspina, nitrate diffusive fluxes were calculated from vertical diffusivity taking into account both mechanical turbulence and salt fingers (FernándezCastro et al., 2015). These features could have important implications for the transport of nutrients and phytoplankton growth, as they mix dissolved substances more efficiently than mechanical turbulence (McDougall and Ruddick, 1992). Since biological fixation of atmospheric $\mathrm{N}_{2}$ by microbial diazotrophs could equal or even exceed nitrate diffusion as a mechanism for new nitrogen supply in tropical and subtropical regions (Capone et al., 2005; Mouriño-Carballido et al., 2011), $\mathrm{N}_{2}$ fixation rates measured with the ${ }^{15} \mathrm{~N}_{2}$ uptake technique (Montoya et al. 1996) were also considered to compute new nitrogen supply in the Malaspina stations (see details in Fernández-Castro et al. 2015).

The Galician Rías are four semienclosed and elongated bays located in the northern limit of the Iberia-Canary Current upwelling domain (Arístegui et al., 2009). The hydrographic and circulation patterns consist of a succession of upwelling and downwelling events driven by the dominant shelf winds (Álvarez-Salgado et al., 2003, 2002). Thus, nutrient input into the Rías occurs mainly by coastal upwelling, while continental runoff and precipitation represent minor inputs (Fernández et al., 2016). New nitrogen supply in the Galician Rias was therefore computed as the sum of nitrate diffusive flux and nitrate supply through vertical advection due to upwelling. The latter was calculated as:

$\mathrm{NO}_{3}^{-}$advective flux $=\frac{Q_{Z}}{A_{\text {basin }}}\left[\mathrm{NO}_{3}^{-}\right]_{\text {bottom }}$ where $\mathrm{Q}_{z}$ is the vertical advective flux calculated as the product of the upwelling index (IW, $\mathrm{m}^{3} \mathrm{~s}^{-1} \mathrm{~km}^{-1}$ ) and the length of the mouth of the Ría (ca. $10 \mathrm{~km}$ for Rías de Vigo and Pontevedra). IW was calculated from wind data recorded at the Silleiro buoy (http://www. indicedeafloramiento.ieo.es) and it was averaged over the 3-day period before each cruise. $A_{\text {basin }}$ is the surface area of the Ría (ca. Ría de Vigo $174 \mathrm{~km}^{2}$; Ría de Pontevedra $121 \mathrm{~km}^{2}$ ) and $\left[\mathrm{NO}_{3}{ }^{-}\right]_{\text {bottom }}$ is the average nitrate concentration at the deepest sampling depth, corresponding to upwelled North Atlantic Central Water (NACW) (ÁlvarezSalgado et al., 1993).

In summary, in this study we considered new nitrogen supply into the euphotic zone by nitrate diffusive flux driven by mechanical turbulence (all regions); nitrate salt-fingers mixing and biological $\mathrm{N}_{2}$ fixation (tropical and subtropical domains); and nitrate supply through vertical advection due to upwelling (Galician coastal upwelling). It is important to note that other nitrogen forms such as $\mathrm{NH}_{4}{ }^{+}$and organic nitrogen, which can be an important component of nitrogen supply, were not taken into account since this information is not available for all the cruises.

\subsection{Light availability}

A proxy for light availability in the mixed layer (LA) was computed from the solar radiation dose used by Vallina and Simó (2007):

$L A=\frac{I_{0}}{k \cdot M L D}\left(1-e^{-k \cdot M L D}\right)$

where $I_{0}, k$, and MLD are, respectively, surface photosynthetically active radiation (surface PAR, $\mathrm{I}_{0}$ ), light attenuation coefficient $(k)$ and mixed layer depth (MLD).

Surface photosynthetic active radiation (sPAR) for each sampling station was considered as the 5-day averaged daily data obtained from satellites (http://globcolour.info). Vertical profiles of PAR were obtained with a Licor PAR sensor (Malaspina, FAMOSO, DISTRALREIMAGE) at 91 stations. In those cruises where the Licor PAR sensor was not available (CHAOS, ASIMUTH), PAR profiles were obtained from the weekly sampling of Instituto Tecnolóxico para o Control do Medio Mariño de Galicia (INTECMAR, http://www.intecmar.gal). $k$ was calculated from PAR profiles using the Lambert-Beer equation (Kirk, 1994).

A Lagrangian approach based on the one-dimensional random-walk algorithm proposed by Ross and Sharples (2004) was used to characterize the vertical displacements of plankton cells induced by turbulence. In practice, these random-walk simulations provided a dynamically-based estimate of the mixed-layer depth. Random-walk simulations, forced with the station-mean turbulent diffusivity profile derived from microstructure measurements, were performed at each sampling station. In those simulations, 100 particles were released at the surface at time zero and allowed to passively diffuse in the background diffusivity profile during $24 \mathrm{~h}$. The mixed layer depth was defined as the depth above which $99 \%$ of the particles were found at the end of the simulation. This method of calculating the mixed layer depth has the advantage, over more classical calculations based on the vertical density distribution, that it explicitly takes into account the diffusive movement of passive particles for a given level of turbulent kinetic energy and background stratification. Conversely, it relies on several assumptions: (1) the diapycnal diffusivity profile is static during the $24 \mathrm{~h}$ of simulation, (2) plankton cells do not actively move through the water column or swim, (3) no significant plankton net growth or decay occurs over the simulation time, and (4) the Osborn scaling for turbulent diffusion in stratified turbulence holds for the weakly stratified mixed layer. The last assumption could be particularly sensitive in open ocean regions with deep mixed layers and very weak background stratification, but it is less important in the coastal areas where either haline or thermal background stratification in the upper layers was always present. 


\subsection{Phytoplankton biomass}

Samples for the determination of nano- and microphytoplankton community composition were collected with Niskin bottles from 2 to 6 depths and fixed with formalin-hexamine solution (Malaspina, FAMOSO) or with Lugol's iodine acidic solution (DISTRAL-REIMAGE, ASIMUTH, CHAOS). Cell counts for diatoms and dinoflagellates were carried out under an inverted microscope following the Utermöhl's (1958) method, and classification was done at the species level when possible. Coccolithophores are not considered in the present study since they were not analyzed in the Galician Rías stations. Coccolithophore abundance is generally very small in inner-shelf waters of the NW Iberian upwelling system (Ausín et al., 2018), so samples are usually not preserved to account them by microscopy. Heterotrophic species of dinoflagellates were differentiated based on literature and not included in the analysis. Cell biovolumes were determined by approximation to the nearest geometric shape (Hillebrand et al., 1999) (Malaspina, DISTRAL-REIMAGE), estimated from data in the literature (Harrison et al., 2015; Margalef, 1994; Sal et al., 2013) (FAMOSO), or estimated (ASIMUTH, CHAOS) from previously determined biovolumes in the region (DISTRAL-REIMAGE). Biovolumes were converted to carbon biomass using empirically-derived carbon to volume conversion factors for diatoms and dinoflagellates (Menden-Deuer and Lessard, 2000). Finally, diatom and dinoflagellate biomass was integrated vertically down to the depth of the deep chlorophyll maximum (DCM) (Malaspina, FAMOSO) or $20 \mathrm{~m}$ (DISTRAL-REIMAGE, ASIMUTH, CHAOS), which can be considered approximately as the depth of the euphotic layer in the Galician upwelling region.

Diatom and dinoflagellate community composition was summarized by means of a Principal Coordinates analysis (PCoA). The analysis was based on the Bray-Curtis dissimilarity matrix among log-transformed biomass data $[\log (\mathrm{x}+1)]$ of 289 taxa present in 98 samples. Given that a large portion of specimens was not identifiable to species level, individuals were grouped into categories such as 'unidentified diatoms' or 'unidentified dinoflagellates'. All calculations were performed using the Fathom Toolbox for Matlab (Jones, 2015).

\subsection{Photosynthetic pigments}

Samples for the determination of photosynthetic pigments were collected at 2-7 depths from Niskin bottles and filtered through GF/F filters (Whatman, $25 \mathrm{~mm}$ ). Filters were preserved in liquid nitrogen until later determination on land by High Performance Liquid Chromatography (HPLC), following the methods described in Zapata et al. (2000) and Latasa (2007). HPLC-determined pigment concentrations were integrated vertically down to depth of the deep chlorophyll maximum (DCM) (Malaspina, FAMOSO) or $20 \mathrm{~m}$ (ASIMUTH, CHAOS). Samples for the determination of photosynthetic pigments were not collected in DISTRAL-REIMAGE cruise.

An estimation of the chlorophyll- $a$ (Chl- $a$ ) of four phytoplankton groups was calculated using HPLC-determined pigment concentrations and the algorithms given in Letelier et al. (1993) for diatoms, dinoflagellates, prymnesiophytes, chrysophytes, cyanobacteria (Synechococcus spp. and Trichodesmium spp.) and Prochlorococcus spp. The sum of prymnesiophytes and chrysophytes was considered as the single group of pico- and nanoeukaryotes and the sum of Synechococcus spp., Trichodesmium spp and Prochlorococcus spp. as cyanobacteria.

\subsection{Overlap between groups along environmental ranges}

Estimations of environmental overlap between diatoms, dinoflagellates, pico- and nanoeukaryotes and cyanobacteria were calculated based on non-parametric kernel density functions (Stine and Heyse, 2001):
$N O_{K_{i, j, t}}=1-\frac{1}{2} \int\left|f_{i t}(x)-f_{j t}(x)\right| d x$

where $\mathrm{f}_{i t}$ and $\mathrm{f}_{j t}$ are the kernel density functions for the factor $t$ and phytoplankton groups $i$ and $j$, respectively.

The four phytoplankton groups were considered based on the estimation of their Chl- $a$ from HPLC-pigments. The factors (predictors of the environmental regime occupied by each group) considered for the analyses were surface nitrate concentration, vertical mixing, new nitrogen supply and light availability. When the contribution of depthintegrated Chl- $a$ for each phytoplankton group exceeded the value expected by chance $(1 / 4)$, predictors for each station were selected. A kernel density estimate is derived from the sum of symmetric probability density functions (kernels). These kernels are centered on each data point and integrate to 1.0 , so that each area is $1 / \mathrm{n}$ (being $n$ the number of data from a sample) and the area under the population density function is 1.0 (Mouillot et al., 2005). The overlap between two phytoplankton groups is the overlapped area of the distribution for each group, ranging from $0 \%$ (no overlap) to $100 \%$ (complete overlap). Statistically, differentiation between the environmental regimes occupied by each phytoplankton group was ascertained by using null models to verify whether overlaps were significantly lower than $100 \%$. Pseudovalues of the test statistic were calculated through randomly permuting groups labels in the corresponding data set over 10,000 runs (Geange et al., 2011). These calculations were carried out in $\mathrm{R}$ (R Development Core Team, 2018) using the source code provided as supporting information by Geange et al. (2011).

\section{Results}

\subsection{Environmental variables and phytoplankton community structure}

Our data set covers a wide range of oceanographic conditions from oligotrophic (tropical and subtropical Atlantic, Pacific and Indian oceans, T), to mesotrophic (northwestern Mediterranean, M), and eutrophic (Galician coastal upwelling, G) environments. Stations sampled in tropical and subtropical regions were characterized by warm surface waters $\left(26 \pm 3{ }^{\circ} \mathrm{C}\right)$, relatively weak new nitrogen supply into the euphotic zone $\left(0.3 \pm 0.6 \mathrm{mmol} \mathrm{m}^{-2} \mathrm{~d}^{-1}\right)$, and low surface Chl- $a$ concentration $\left(0.2 \pm 0.1 \mathrm{mg} \mathrm{m}^{-3}\right)$ (Table 2 and Fig. 3). In the Mediterranean, surface waters were cooler $\left(16 \pm 4{ }^{\circ} \mathrm{C}\right)$ and characterized by intermediate values of new nitrogen supply $\left(4 \pm 6 \mathrm{mmol} \mathrm{m}^{-2} \mathrm{~d}^{-1}\right)$ and surface Chl- $a\left(0.8 \pm 0.9 \mathrm{mg} \mathrm{m}^{-3}\right)$. Finally, the Galician upwelling region was also characterized by relatively cold surface waters $\left(16 \pm 2{ }^{\circ} \mathrm{C}\right)$, elevated new nitrogen supply $\left(30 \pm 29 \mathrm{mmol} \mathrm{m}^{-2} \mathrm{~d}^{-1}\right)$ and enhanced surface Chl- $a$ concentration $\left(4 \pm 4 \mathrm{mg} \mathrm{m}^{-3}\right.$ ). The proxy for light availability, computed considered surface PAR and mixing conditions (see Methods), took significantly higher values in tropical and subtropical regions $\left(27 \pm 11 \mathrm{E} \mathrm{m}^{-2} \mathrm{~d}^{-1}\right)$ than in the Galician upwelling $\left(16 \pm 7 \mathrm{E} \mathrm{m}^{-2} \mathrm{~d}^{-1}\right)$.

Biomass estimations derived from cell volume measurements obtained with microscopy and Chl- $a$ estimations derived from HPLC-pigments concentration were both used independently to characterize the composition of the phytoplankton community. With microscopy is not possible to obtain a good discrimination of pico- and nanoplankton cells because, due to their small size, they are usually unidentified or even overlooked. Thus, while microscopy provides only reliable information on large cells, with HPLC-pigments is possible to study the whole phytoplankton community. The use of both techniques separately provides a comprehensive description of the structure of the phytoplankton community. Both microscopy and HPLC-pigments data were available in all the stations collected during the Malaspina expedition (mainly of tropical and subtropical regions), and in the NW Mediterranean and other regions. However, in the Galician upwelling region, data from both techniques were only available at few stations (Fig. 2). As shown in Table 2, in the Galician upwelling, diatoms had 
Table 2

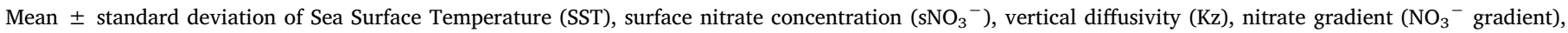

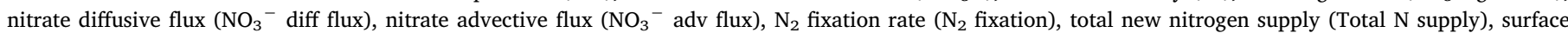

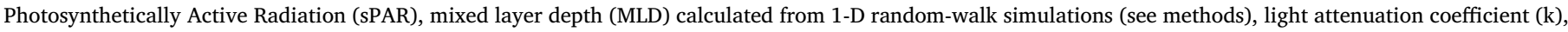

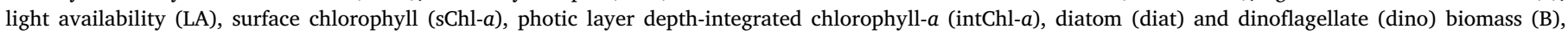

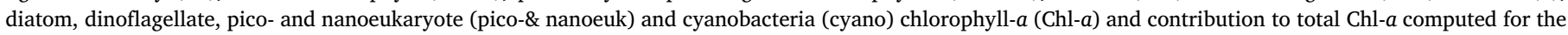

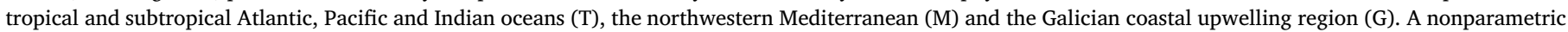

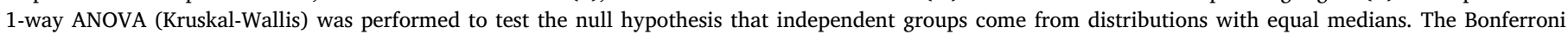

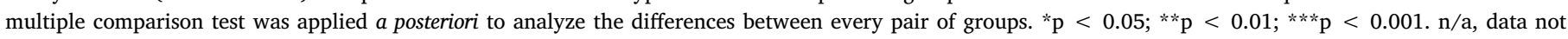
available.

\begin{tabular}{|c|c|c|c|c|c|}
\hline & $\mathrm{T}$ & M & G & $\begin{array}{l}\text { KW } \\
\text { p-value }\end{array}$ & Post hoc Bonferron \\
\hline SST $\left({ }^{\circ} \mathrm{C}\right)$ & $26 \pm 3$ & $16 \pm 4$ & $16 \pm 2$ & $<0.001^{* * *}$ & $\mathrm{~T}>\mathrm{M}, \mathrm{G}$ \\
\hline $\mathrm{sNO}_{3}^{-}\left(\mathrm{mmol} \mathrm{m}^{-3}\right)$ & $0.4 \pm 0.7$ & $2.2 \pm 1.6$ & $1.6 \pm 2.0$ & $<0.001 * * *$ & $\mathrm{~T}<\mathrm{G}<\mathrm{M}$ \\
\hline $\mathrm{Kz} \times 10^{-4}\left(\mathrm{~m}^{2} \mathrm{~s}^{-1}\right)$ & $0.4 \pm 1.0$ & $2 \pm 3$ & $4 \pm 5$ & $<0.001 * * *$ & $\mathrm{~T}<\mathrm{M}, \mathrm{G}$ \\
\hline $\mathrm{NO}_{3}{ }^{-}$gradient $\left(\mathrm{mmol} \mathrm{m}^{-4}\right)$ & $0.12 \pm 0.11$ & $0.10 \pm 0.04$ & $0.17 \pm 0.10$ & $<0.05^{*}$ & $\mathrm{~T}<\mathrm{G}$ \\
\hline $\mathrm{NO}_{3}{ }^{-}$diff flux ( $\left.\mathrm{mmol} \mathrm{m}{ }^{-2} \mathrm{~d}^{-1}\right)$ & $0.28 \pm 0.55$ & $4 \pm 6$ & $5 \pm 10$ & & \\
\hline $\mathrm{NO}_{3}{ }^{-}$adv flux $\left(\mathrm{mmol} \mathrm{m}^{-2} \mathrm{~d}^{-1}\right)$ & $\mathrm{n} / \mathrm{a}$ & $\mathrm{n} / \mathrm{a}$ & $25 \pm 25$ & & \\
\hline $\mathrm{N}_{2}$ fixation $\left(\mathrm{mmol} \mathrm{m}^{-2} \mathrm{~d}^{-1}\right)$ & $0.01 \pm 0.01$ & $\mathrm{n} / \mathrm{a}$ & $\mathrm{n} / \mathrm{a}$ & & \\
\hline Total $\mathrm{N}$ supply (mmol m${ }^{-2} \mathrm{~d}^{-1}$ ) & $0.29 \pm 0.55$ & $4 \pm 6$ & $30 \pm 29$ & $<0.001 * * *$ & $\mathrm{~T}<\mathrm{M}<\mathrm{G}$ \\
\hline $\operatorname{sPAR}\left(\mathrm{E} \mathrm{m}^{-2} \mathrm{~d}^{-1}\right)$ & $47 \pm 10$ & $43 \pm 9$ & $38 \pm 13$ & $<0.01^{* *}$ & $\mathrm{~T}>\mathrm{G}$ \\
\hline $\operatorname{MLD}(\mathrm{m})$ & $32 \pm 17$ & $26 \pm 9$ & $14 \pm 5$ & $<0.001 * * *$ & $\mathrm{~T}, \mathrm{M}>\mathrm{G}$ \\
\hline $\mathrm{k}\left(\mathrm{m}^{-1}\right)$ & $0.05 \pm 0.01$ & $0.08 \pm 0.02$ & $0.17 \pm 0.03$ & $<0.001^{* * *}$ & $\mathrm{~T}<\mathrm{M}<\mathrm{G}$ \\
\hline $\mathrm{LA}\left(\mathrm{E} \mathrm{m}^{-2} \mathrm{~d}^{-1}\right)$ & $27 \pm 11$ & $19 \pm 8$ & $16 \pm 7$ & $<0.001^{* * *}$ & $\mathrm{~T}>\mathrm{G}$ \\
\hline $\mathrm{sChl}-a\left(\mathrm{mg} \mathrm{C} \mathrm{m}^{-3}\right)$ & $0.2 \pm 0.1$ & $0.8 \pm 0.9$ & $4 \pm 4$ & $<0.001 * * *$ & $\mathrm{~T}<\mathrm{M}<\mathrm{G}$ \\
\hline intChl- $a\left(\mathrm{mg} \mathrm{C} \mathrm{m}^{-2}\right)$ & $29 \pm 9$ & $64 \pm 105$ & $134 \pm 115$ & $<0.001^{* * *}$ & $\mathrm{~T}, \mathrm{M}<\mathrm{G}$ \\
\hline Diatom Chl- $a\left(\mathrm{mg} \mathrm{m}^{-2}\right)$ & $0.13 \pm 0.15$ & $1.5 \pm 2.1$ & $34 \pm 14$ & $<0.001^{* * *}$ & $\mathrm{~T}<\mathrm{M}, \mathrm{G}$ \\
\hline Dinoflagellate Chl- $a\left(\mathrm{mg} \mathrm{m}^{-2}\right)$ & $0.3 \pm 0.2$ & $0.58 \pm 0.59$ & $10.4 \pm 9.7$ & $<0.001^{* * *}$ & $\mathrm{~T}, \mathrm{M}<\mathrm{G}$ \\
\hline Pico- \& nanoeuk Chl- $a\left(\mathrm{mg} \mathrm{m}^{-2}\right)$ & $6 \pm 3$ & $6 \pm 7$ & $1.9 \pm 1.7$ & $<0.001 * *$ & $\mathrm{~T}, \mathrm{M}>\mathrm{G}$ \\
\hline Cyano Chl- $a\left(\mathrm{mg} \mathrm{m}^{-2}\right)$ & $12 \pm 5$ & $5 \pm 3$ & $1.3 \pm 0.8$ & $<0.001^{* * *}$ & $\mathrm{~T}>\mathrm{M}, \mathrm{G}$ \\
\hline Diatom Chl- $a(\%)$ & $0.7 \pm 0.6$ & $9 \pm 9$ & $63 \pm 23$ & $<0.001^{* * *}$ & $\mathrm{~T}<\mathrm{M}, \mathrm{G}$ \\
\hline Dinoflagellate Chl- $a(\%)$ & $2 \pm 1$ & $4 \pm 3$ & $25 \pm 16$ & $<0.001^{* * *}$ & $\mathrm{~T}<\mathrm{M}<\mathrm{G}$ \\
\hline Pico- \& nanoeuk Chl- $a(\%)$ & $31 \pm 8$ & $38 \pm 20$ & $7 \pm 8$ & $<0.001^{* * *}$ & $\mathrm{~T}, \mathrm{M}>\mathrm{G}$ \\
\hline Cyano Chl- $a(\%)$ & $67 \pm 9$ & $50 \pm 28$ & $4 \pm 2$ & $<0.001^{* * *}$ & $\mathrm{~T}, \mathrm{M}>\mathrm{G}$ \\
\hline Diatom B $\left(\mathrm{mg} \mathrm{Cm}^{-2}\right)$ & $36 \pm 92$ & $58 \pm 85$ & $1370 \pm 1922$ & $<0.001 * * *$ & $\mathrm{~T}, \mathrm{M}<\mathrm{G}$ \\
\hline Dinoflagellate B $\left(\mathrm{mg} \mathrm{C} \mathrm{m}^{-2}\right)$ & $124 \pm 60$ & $675 \pm 992$ & $398 \pm 589$ & $<0.01^{* *}$ & $\mathrm{~T}, \mathrm{G}<\mathrm{M}$ \\
\hline Total B $\left(\mathrm{mg} \mathrm{C} \mathrm{m}^{-2}\right)$ & $161 \pm 114$ & $734 \pm 1051$ & $1768 \pm 2433$ & $<0.001^{* * *}$ & $\mathrm{~T}<\mathrm{G}, \mathrm{M}$ \\
\hline
\end{tabular}

the highest contribution to total Chl- $a$ derived from HPLC-pigments (63 $\pm 23 \%$ ), followed by dinoflagellates $(25 \pm 16 \%)$, pico- and nanoeukaryotes $(7 \pm 8 \%)$ and cyanobacteria $(4 \pm 2 \%)$. Tropical and subtropical regions and the Mediterranean exhibited a higher contribution of cyanobacteria ( $67 \pm 9$ and $50 \pm 28 \%$, respectively), followed by pico- and nanoeukaryotes $(31 \pm 8 \%$ and $38 \pm 20 \%$, respectively) and dinoflagellates ( $2 \pm 1 \%$ and $4 \pm 3 \%$, respectively). However, the contribution of diatoms was higher in the Mediterranean ( $9 \pm 9 \%$ ), compared to the oligotrophic tropical and subtropical regions $(0.7 \pm 0.6 \%)$.

Depth-integrated biomass of diatoms derived from microscopy was highest in the Galician upwelling system $\left(1370 \pm 1922 \mathrm{mg} \mathrm{C}^{-2}\right)$, where it represented, on average, $77 \%$ of the sum of diatom and dinoflagellate biomass. Dinoflagellate biomass was higher in the Mediterranean $\left(675 \pm 992 \mathrm{mg} \mathrm{C} \mathrm{m}^{-2}\right)$, where it contributed ca. $92 \%$ of the combined diatom and dinoflagellate biomass. In the tropical and subtropical regions the relatively low dinoflagellate biomass (124 $\pm 60 \mathrm{mg} \mathrm{C} \mathrm{m}^{-2}$ ) contributed ca. $77 \%$ of the combined diatom and dinoflagellate biomass. The species composition of diatoms and dinoflagellates derived from microscopy in the three regions was investigated by Principal Coordinates Analysis (PCoA) (Fig. 4), in order to summarize the biomass data of the 289 taxa determined in 98 stations. The analyses revealed that the first two axes (PCO1 and PCO2) explained ca. $37 \%$ of the total variance, and that the first axis clearly separated the samples from the three regions. Superimposing vectors indicate that species of diatoms (Chaetoceros spp., Pseudo-nitzschia spp., Guinardia delicatula, Leptocylindrus danicus, Rhizosolenia shrubsolei, Detonula pumila) dominated the biomass in the Galician upwelling region. However, unidentified dinoflagellates clearly dominated over diatoms in tropical and subtropical regions.

\subsection{Mixing and resource availability as drivers of community structure}

HPLC-derived Chl- $a$ estimates for the different groups allowed us to analyze the role of environmental factors as drivers of variability in phytoplankton community structure (Fig. 5). Simple linear relationships were computed between surface nitrate concentration, vertical mixing, new nitrogen supply, light availability and biomass estimates for the four phytoplankton groups. Only diatom Chl- $a$ was positively correlated with surface nitrate concentration $\left(\mathrm{R}^{2}=0.14, \mathrm{p}<0.01\right)$. Significant relationships were found between vertical mixing and the Chl- $a$ of all phytoplankton groups, except in the case of pico- and nanoeukaryotes. These relationships were positive for diatoms $\left(\mathrm{R}^{2}=0.24, \mathrm{p}<0.01\right)$ and dinoflagellates $\left(\mathrm{R}^{2}=0.08, \mathrm{p}<0.01\right)$, and negative for cyanobacteria $\left(R^{2}=0.29, \mathrm{p}<0.01\right)$. All phytoplankton groups were significantly correlated with new nitrogen supply. Diatom and dinoflagellate Chl- $a$ increase with new nitrogen supply $\left(\mathrm{R}^{2}=0.52\right.$, $\mathrm{p}<0.01$ and $\mathrm{R}^{2}=0.23, \mathrm{p}<0.01$, respectively), whereas for picoand nanoeukaryotes and cyanobacteria, the relationship was negative $\left(\mathrm{R}^{2}=0.13, \mathrm{p}<0.01\right.$ and $\mathrm{R}^{2}=0.39, \mathrm{p}<0.01$, respectively). Light availability showed a negative relationship with diatom Chl- $a$ $\left(\mathrm{R}^{2}=0.20, \mathrm{p}<0.01\right)$ and a positive but weaker relationship with cyanobacteria $\left(\mathrm{R}^{2}=0.09, \mathrm{p}<0.01\right)$.

The role of mixing and new nitrogen supply in structuring the composition of the phytoplankton community was also highlighted by using non-parametric kernel density functions to characterize the degree of overlapping between the environmental regimes occupied by the four phytoplankton groups (Fig. 6). Vertical mixing, new nitrogen supply and light availability allowed a statistically significant distinction between the distribution of some of the groups (Table 3). The distinction between diatoms and dinoflagellates (large cells) and picoand nanoeukaryotes and cyanobacteria (small cells) was better defined 

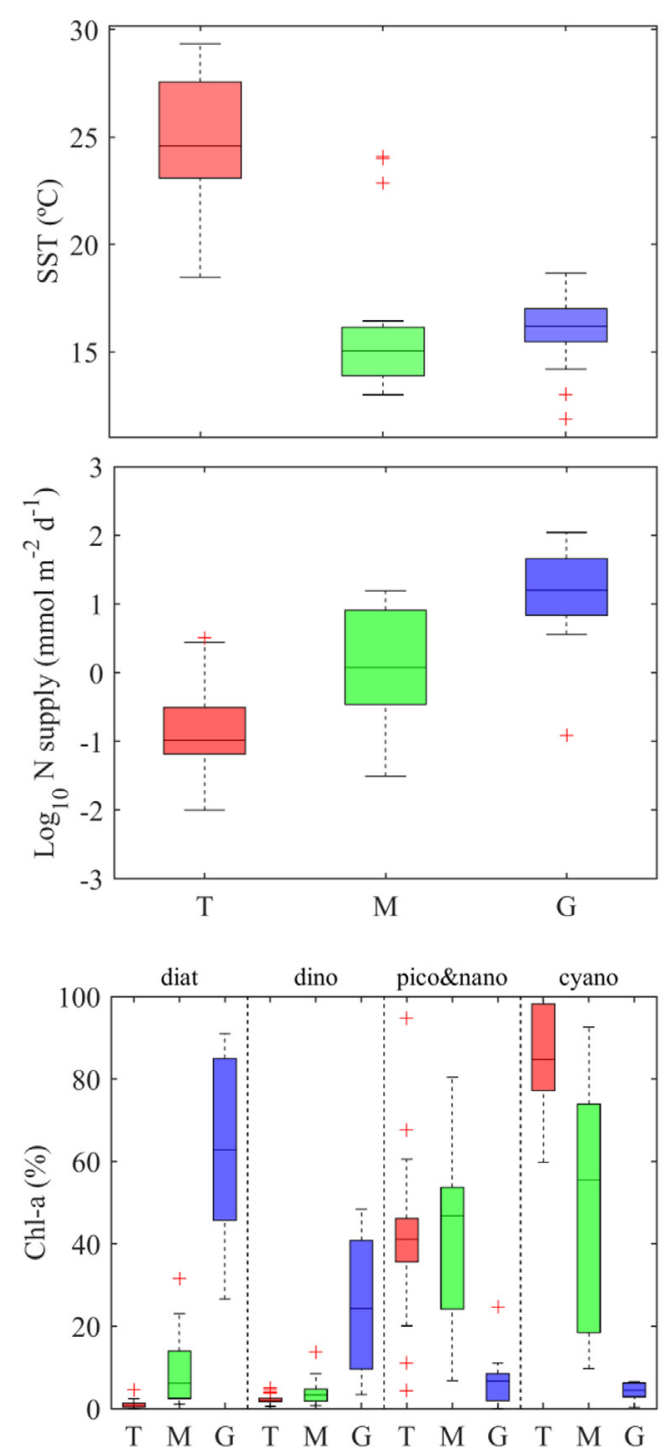
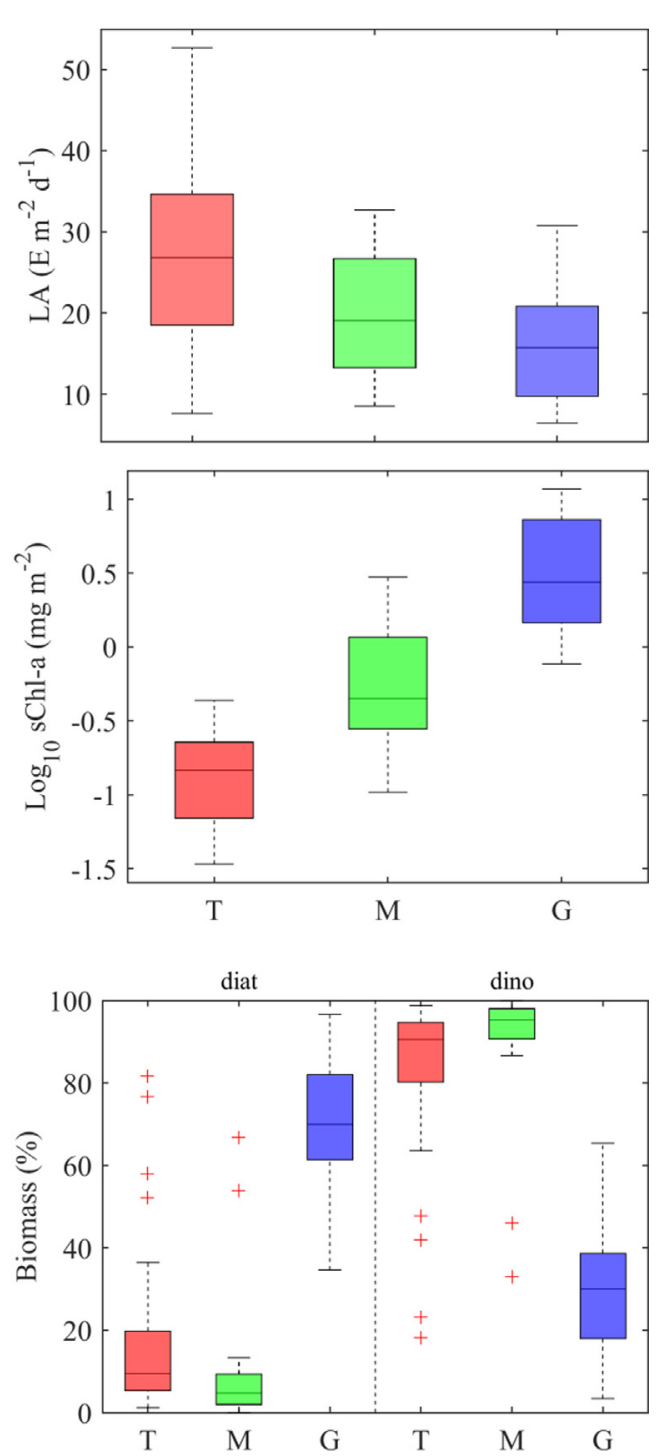

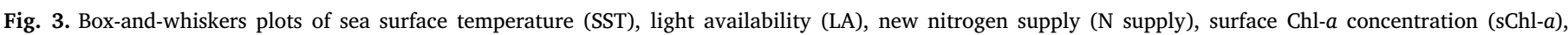

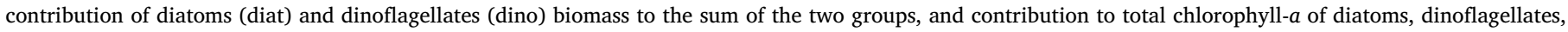

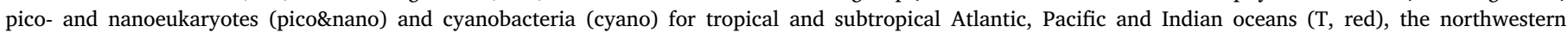

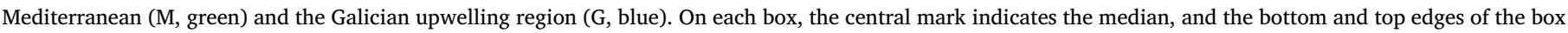

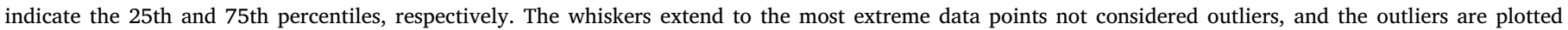
individually using the '+' symbol. (For interpretation of the references to color in this figure legend, the reader is referred to the web version of this article.)

by new nitrogen supply and vertical mixing than by light availability. The overlapping in terms of new nitrogen supply between diatoms and cyanobacteria was only 5\% ( $\mathrm{p}<0.001)$, and between diatoms and pico- and nanoeukaryotes was $13 \%(\mathrm{p}<0.001)$. For dinoflagellates, the overlapping with cyanobacteria was $3 \%(\mathrm{p}<0.001)$ and with pico- and nanoeukaryotes $10 \% \quad(\mathrm{p}<0.001)$. Regarding vertical mixing, the overlapping between diatoms and pico- and nanoeukaryotes and cyanobacteria was 51\% $(\mathrm{p}<0.05)$ and $45 \%(\mathrm{p}<0.01)$, respectively. The overlapping along the range of vertical mixing between dinoflagellates and pico- and nanoeukaryotes and cyanobacteria was $17 \%$ and $16 \%$, respectively ( $\mathrm{p}<0.01$ ). Finally, light availability yielded statistically significant differences only between diatoms and pico- and nanoeukaryotes $(57 \%, \mathrm{p}<0.05)$ and between diatoms and cyanobacteria $(52 \%, \mathrm{p}<0.01)$.

The relationship between environmental factors and the biomass of diatoms and dinoflagellates determined by microscopy is examined in Fig. 7. While diatom biomass showed statistically significant positive relationships with surface nitrate concentration $\left(\mathrm{R}^{2}=0.10, \mathrm{p}<0.01\right)$, vertical mixing $\left(\mathrm{R}^{2}=0.30, \mathrm{p}<0.01\right)$ and new nitrogen supply
$\left(\mathrm{R}^{2}=0.34, \mathrm{p}<0.01\right)$, dinoflagellates was positively correlated only with surface nitrate concentration $\left(\mathrm{R}^{2}=0.07, \mathrm{p}<0.01\right)$. The diatom contribution to the sum of diatom and dinoflagellate biomass only presented statistically significant relationships with vertical mixing $\left(\mathrm{R}^{2}=0.31, \mathrm{p}<0.01\right)$ and new nitrogen supply $\left(\mathrm{R}^{2}=0.48\right.$, $\mathrm{p}<0.01)$. Finally, no significant relationship was found between light availability and the absolute or relative biomass of either phytoplankton group.

To summarize these results in the framework of the model proposed by Margalef, a novel evaluation of the original mandala was generated, redefining its y-axis as new nitrogen supply and including the mixing domains indicated by Margalef for diatoms and dinoflagellates. Chl- $a$ and biomass estimations derived from HPLC-pigments and microscopy approaches, respectively, were used to place the phytoplankton in the mandala. The group representing the largest contribution to Chl- $a$ and the diatom contribution to the total biomass of diatoms and dinoflagellates are indicated by different colors and circle sizes, respectively, in Fig. 8.

Cyanobacteria dominance was constrained to low values of mixing 


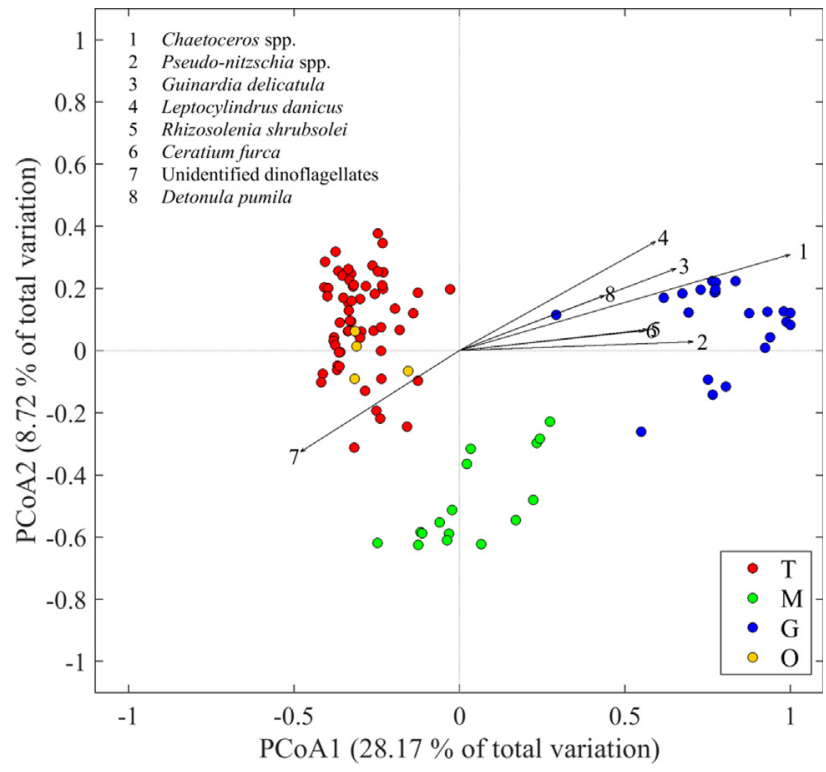

Fig. 4. Principal Coordinates Analysis (PCoA) ordination diagram of diatom and dinoflagellate biomass for tropical and subtropical Atlantic, Pacific and Indian oceans ( $\mathrm{T}$, red), the Mediterranean (M, green), the Galician upwelling region ( $\mathrm{G}$, blue) and other regions (O, orange). Vectors correspond to the eight taxa with highest correlations with PCoA axis 1 and 2. The length and direction of each vector indicates the strength and sign, respectively, of the correlation. Percentage of variance explained by PCoA axis 1 and 2 is also indicated. (For interpretation of the references to color in this figure legend, the reader is referred to the web version of this article.)

levels and new nitrogen supply, pico- and nanoeukaryotes dominated in a wide range of both factors, and finally diatoms and dinoflagellates were dominant at higher new nitrogen supply (Fig. 8A). However, whereas dinoflagellates were restricted to intermediate mixing levels, diatoms covered a wider spectrum of mixing, exceeding the range proposed by Margalef for their dominance $\left(2-100 \mathrm{~cm}^{2} \mathrm{~s}^{-1}\right.$, grey area) towards lower values. In the mixing range originally proposed for dinoflagellates $\left(0.02-1 \mathrm{~cm}^{2} \mathrm{~s}^{-1}\right)$, cyanobacteria mainly dominated the community. Accordingly, the results from microscopy data showed that, in general, the diatom contribution to the sum of diatom and dinoflagellate biomass increased with mixing and new nitrogen supply (Fig. 8C).

However, some exceptions to the general trend were observed, revealing some processes that were not included in the original mandala. Two points sampled in the Galician upwelling region in spring showed diatom dominance (Fig. 8A) and $>75 \%$ of diatom contribution (Fig. 8C) at low mixing and high new nitrogen supply (indicated by markers with a thick line width). In these stations phytoplankton thin layers were observed in the fluorescence vertical profiles, coinciding with the region of the water column where mixing values were lower (Fig. 9). Three stations sampled in the northwestern Mediterranean in winter (FAMOSO I) showed pico- and nanoeukaryote dominance at high mixing and new nitrogen supply values (Fig. 8A). Finally, two points of $>75 \%$ of diatom contribution (Fig. 8C) are distinguished in the dinoflagellates mixing region at low new nitrogen supply. These stations were sampled in the South Atlantic and the Indian Subtropical Gyres during Malaspina (stations 29 and 56, respectively; see supplementary material of Fernández-Castro et al., 2015), coinciding with a high abundance of a diatom that has a nitrogen-fixing cyanobacteria as an endosymbiont. These exceptions are discussed in more detail in Section 4.2.

\section{Discussion}

\subsection{Factors controlling phytoplankton community structure}

Our analysis of vertical mixing, nitrate concentration, new nitrogen supply, light availability and phytoplankton community data collected in contrasting marine environments showed that mixing and nitrate supply play an important role on determining the phytoplankton community structure. At lower values of mixing and new nitrogen supply cyanobacteria dominated; pico- and nanoeukaryotes were dominant across a wide range of both environmental variables, and finally enhanced new nitrogen supply was favourable for diatoms and dinoflagellates. However, while dinoflagellates were prevalent at intermediate mixing levels, diatoms spread across a wider range of mixing conditions. These results are consistent with the few studies that had previously investigated the role of these environmental factors on phytoplankton, including observations of microstructure turbulence collected in the field, or indirect estimates. By using partially the same set of stations used in this study data, Otero-Ferrer et al. (2018) extended the analysis described in Mouriño-Carballido et al. (2016) and concluded that nitrate supply was the only factor that allowed the distinction between the ecological niches of the autotrophic and heterotrophic picoplankton subgroups. Barton et al. (2015) analyzed diatom and dinoflagellate abundance and biomass data from the Continuous Plankton Recorder in connection with environmental variability in the North Atlantic over a 50-year period. They found that seasonal changes in phytoplankton are controlled by the availability of light and nutrients.

Our results are, in general, consistent with the widely accepted idea that small phytoplankton cells dominate in oligotrophic regions and, in contrast, larger phytoplankton dominates in eutrophic environments (temperate shelf seas or upwelling zones) (Chisholm, 1992; Kiørboe, 1993; Marañón, 2015). Nitrogen is the most frequently limiting nutrient in marine environments and the different functional groups are able to use different nitrogen forms. $\mathrm{NH}_{4}{ }^{+}$has been traditionally considered the preferred form of nitrogen for phytoplankton due to its lower energetic costs of uptake and assimilation, and it can even produce repression of $\mathrm{NO}_{3}{ }^{-}$uptake and assimilation (Glibert et al., 2016 and references therein). However, large cells such as diatoms tend to show a stronger preference for $\mathrm{NO}_{3}{ }^{-}$, compared with small cells, and they are able to use and store $\mathrm{NO}_{3}{ }^{-}$even when $\mathrm{NH}_{4}{ }^{+}$is available in excess (Lomas and Glibert, 1999a). Uptake of $\mathrm{NO}_{3}{ }^{-}$and $\mathrm{NH}_{4}{ }^{+}$are associated with new and regenerated production, respectively (Dugdale and Goering, 1987). New production is dominated by large phytoplankton, such as diatoms, whereas regenerated production, based on $\mathrm{NH}_{4}{ }^{+}$and urea, is dominated by mixotrophic dinoflagellates, small eukaryotic algae, cyanobacteria and bacteria (Dugdale and Goering, 1987; Legendre and Rassoulzadegan, 1995). Unfortunately, our dataset only allows to evaluate the role of new nitrogen supply (nitrate and biological nitrogen fixation) instead of total nitrogen supply (new and regenerated forms) on phytoplankton community composition.

These results pointed to a differential response of the phytoplankton groups to turbulence and nutrient supply depending on their functional traits. Under calm conditions, small and motile cells are better competitors for limiting nutrients due to their large surface to volume ratio and the increased nutrient supply to cells through swimming, respectively, whereas enhancement of nutrient uptake in turbulent environments is greatest for larger cells (Falkowski and Oliver, 2007; Peters et al., 2006; Prairie et al., 2012). Moreover, low mixing conditions also select for small cells as large and non-motile phytoplankton tend to sink rapidly in the water column if there is not enough turbulence to maintain them suspended. On the other hand, strong turbulence can cause physical and physiological damage and modifications in the behavior of dinoflagellates, as shown in laboratory experiments (Berdalet et al., 2007). There is also abundant field and laboratory evidence that large diatoms are able to regulate their buoyancy to obtain nutrients 

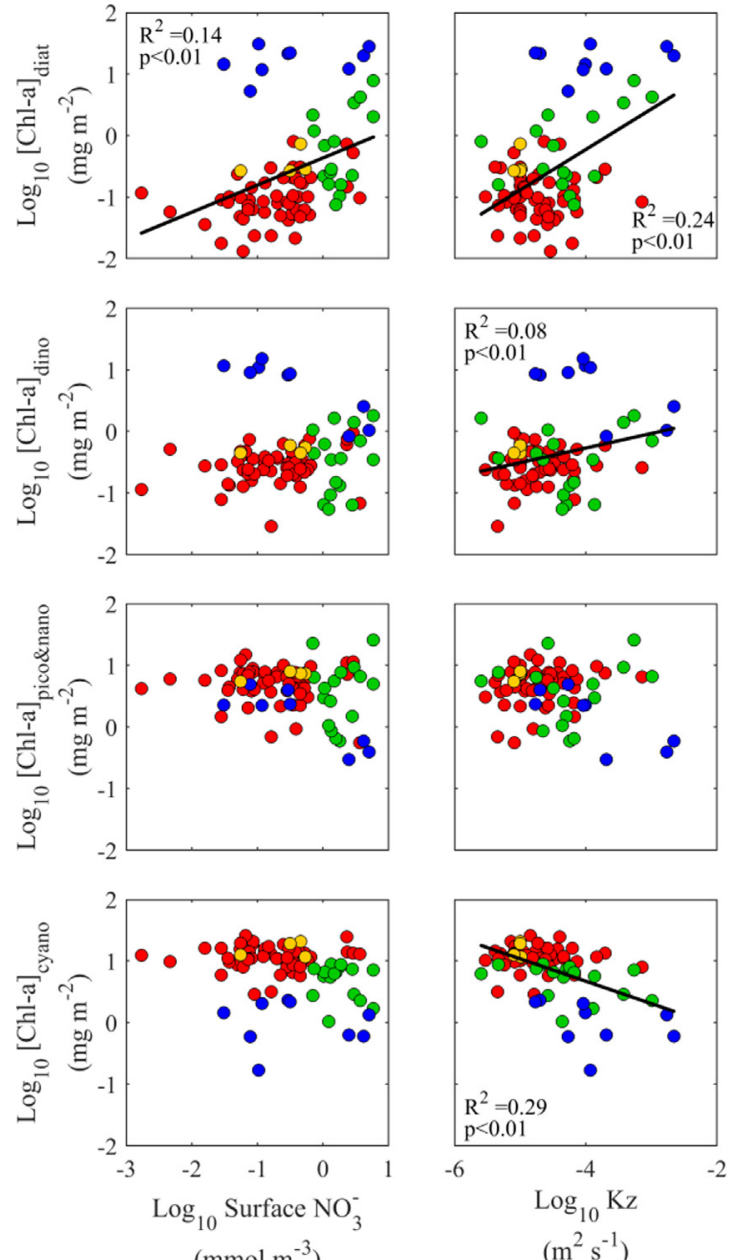

$\left(\mathrm{m}^{2} \mathrm{~s}^{-1}\right)$
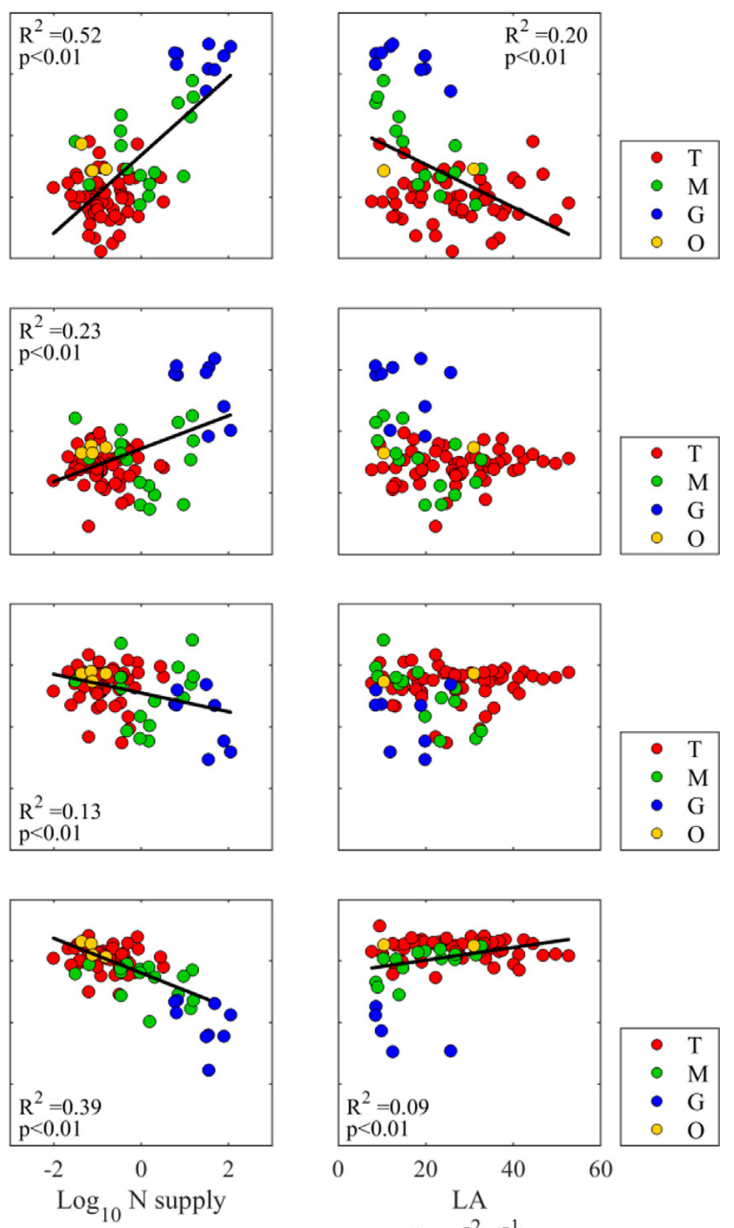

$\left(\mathrm{mmol} \mathrm{m} \mathrm{d}^{-2}\right)$

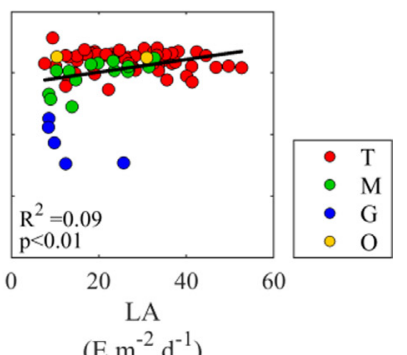

$\left(E \mathrm{~m}^{-2} \mathrm{~d}^{-1}\right)$

Fig. 5. HPLC-derived chlorophyll- $a$ contribution of four phytoplankton groups (diatoms, dinoflagellates, pico- and nanoeukaryotes and cyanobacteria) against surface nitrate concentration (surface $\mathrm{NO}_{3}{ }^{-}$), vertical mixing (Kz), new nitrogen supply ( $\mathrm{N}$ supply) and light availability (LA) in the tropical and subtropical Atlantic and Pacific oceans ( $\mathrm{T}$, red), the Mediterranean (M, green), the Galician upwelling region (G, blue), and other regions (O, orange). Black lines indicate statistically significant relationships. Variables that did not follow normal distributions were log-transformed. (For interpretation of the references to color in this figure legend, the reader is referred to the web version of this article.)

from depth and then migrate to higher light levels (Villareal et al., 2014). Our results, showing that the environmental regime occupied by diatoms is not restricted to high values of mixing, support the idea that some diatoms present adaptations that allow them to reach relatively high abundances also in stratified waters (Kemp and Villareal, 2018).

The different functional groups present contrasting nutrient uptake and utilization strategies. Diatoms possess high maximum nutrient uptake and growth rates, which allow them to exploit intermittent nutrient pulses (Litchman, 2007; Sommer, 1984). They are also storage specialists, utilizing nutrient pulses for luxury consumption by storing nutrients in vacuoles until the next pulse (Cermeño et al., 2011). Dinoflagellates have lower maximum uptake and growth rates than diatoms, but mixotrophy and motility makes them better adapted to grow under low nutrient conditions (Smayda, 1997) allowing them to proliferate in a diversity of habitats. Picophytoplankton cells are adapted to low nutrient conditions thanks to their large surface to volume ratio and also because they invest heavily in resource-acquisition machinery, which allows them to maintain growth when resources are low, in what is known as the "gleaners" or "survivalist" strategy (Arrigo, 2005).

Other environment factors that potentially control phytoplankton growth, such as light availability, were also discussed in Margalef's original work. Later, the Reynolds Intaglio (Reynolds, 1987) considered irradiance (in a combination with mixing depth) as one of the principal factors that structure phytoplankton communities. Recently, Glibert
(2016) included the physiological adaptation to high or low light in her twelve-dimensions mandala. Irwin et al. (2012) considered the mean irradiance over the mixed layer, which was calculated using temperature and density criteria, when studying diatom and dinoflagellate niches in the North Atlantic. In our study, a proxy for light availability in the mixed layer was calculated using diffusivity estimates derived from microturbulence observations to calculate the mixed layer depth. In general, the groups associated with conditions of low new nitrogen supply tend to be more abundant when light availability is high (picoand nanoeukaryotes and cyanobacteria) and vice versa (diatoms and dinoflagellates). This distinction separates significantly the diatoms from pico- and nanoeukaryotes and cyanobacteria. Similarly, Brun et al. (2015), using the MAREDAT database, found that diatom niches are centered around high nutrient and low light availability, whereas the opposite was true for coccolithophores. However, we observed that the overlapping between groups along the range of light availability was substantially higher than for new nitrogen supply. In this regard, OteroFerrer et al. (2018) concluded that surface radiation was less important than nitrate supply in predicting the biomass of most autotrophic and heterotrophic picoplankton subgroups, except for Prochlorococcus and low-nucleic-acid prokaryotes, for which irradiance also played a significant role. Diatoms have low half-saturation constants for irradiancedependent growth (Richardson et al., 1983) which provides an additional physiological basis for the commonly observed dominance of this 

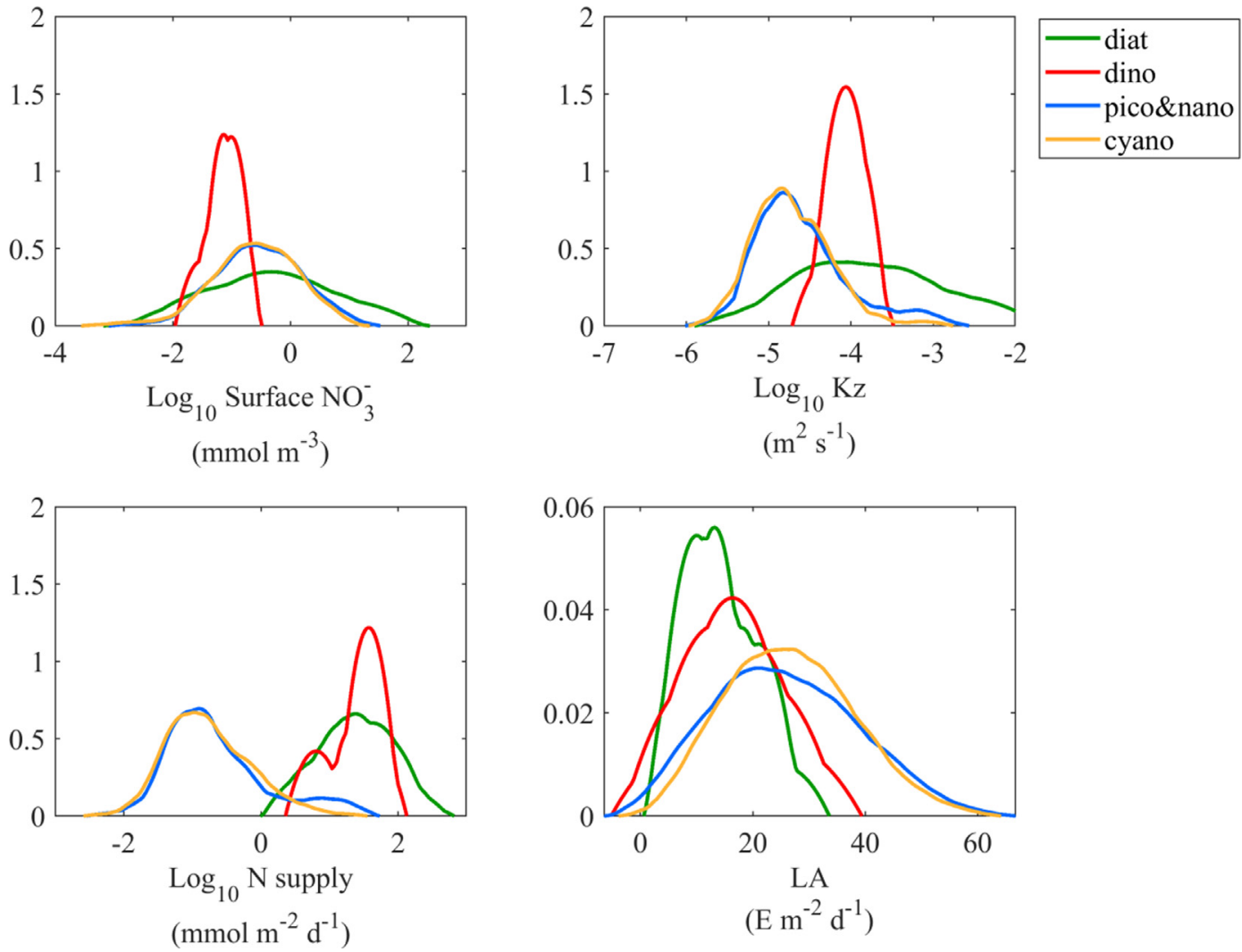

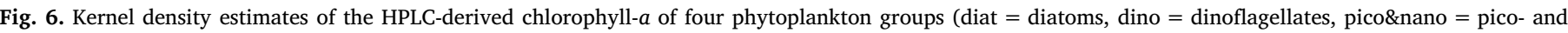

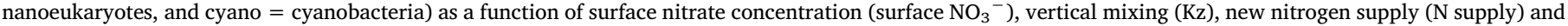
light availability (LA).

Table 3

Environmental overlap (\%) between phytoplankton groups $($ diat $=$ diatoms, dino $=$ dinoflagellates, pico\&nano $=$ pico- and nanoeukaryotes, cyano = cyanobacteria) for surface nitrate concentration $\left(\mathrm{sNO}_{3}{ }^{-}\right)$, vertical diffusivity (Kz), new nitrogen supply (N supply) and light availability (LA). Pairs occupying significantly different environmental ranges are indicated as ${ }^{*} \mathrm{p}<0.05$; $* * \mathrm{p}<0.01 ; * * * \mathrm{p}<0.001$.

\begin{tabular}{|c|c|c|c|c|c|}
\hline & & diat & dino & pico\&nano & cyano \\
\hline \multirow[t]{4}{*}{$\mathrm{sNO}_{3}{ }^{-}$} & diat & 100 & & & \\
\hline & dino & 35 & 100 & & \\
\hline & pico\&nano & 81 & 39 & 100 & 95 \\
\hline & cyano & 77 & 39 & 95 & 100 \\
\hline \multirow[t]{4}{*}{$\mathrm{Kz}$} & diat & 100 & & & \\
\hline & dino & $27^{*}$ & 100 & & \\
\hline & pico\&nano & $51^{*}$ & $16^{* *}$ & 100 & 92 \\
\hline & cyano & $45^{* *}$ & $17^{* *}$ & 92 & 100 \\
\hline \multirow[t]{4}{*}{ N supply } & diat & 100 & & & \\
\hline & dino & 65 & 100 & & \\
\hline & pico\&nano & $13^{* * *}$ & $10^{* * *}$ & 100 & \\
\hline & cyano & $5^{* * *}$ & $3 * * *$ & 91 & 100 \\
\hline \multirow[t]{4}{*}{ LA } & diat & 100 & & & \\
\hline & dino & 87 & 100 & & \\
\hline & pico\&nano & $57^{*}$ & 67 & 100 & \\
\hline & cyano & $52^{* *}$ & 63 & 92 & 100 \\
\hline
\end{tabular}

group in waters with high levels of mixing. Since many of the hydrodynamic processes that alter nutrient regimes also cause light fluctuations for phytoplankton (Litchman, 2007), it is difficult to distinguish the independent effect of each variable in the field.

Temperature is another factor to consider in the study of the environmental controls on phytoplankton communities (Reynolds, 1999). Some studies suggest direct (Hilligsøe et al., 2011; Morán et al., 2010) effects of temperature on phytoplankton size-structure. Other studies suggest indirect effects, like a temperature regulation of nitrate uptake which provides a competitive advantage to diatoms in cold temperatures (Lomas and Glibert, 1999b). However, given that nutrient availability often covaries with temperature in the ocean (Kamykowski and Zentara, 1986), it is difficult to separate the role of these two factors in the field (Agawin et al., 2000), unless large datasets including contrasting conditions are considered. When observations of all combinations of temperature and resource (light and nutrients) supply are considered, the latter factor has been demonstrated to drive the variability in phytoplankton size structure (Marañón, 2015; Sommer et al., 2017). In order to investigate the role of temperature as an environmental control factor in our dataset, environmental overlapping analysis was also conducted using sea surface temperature data (not shown). This analysis revealed a statistically significant distinction between diatoms and dinoflagellates (cold waters) and pico- and nanoeukaryotes and cyanobacteria (warm waters), with an overlapping lower than $12 \%$ ( $<0.001$ ) in all cases. This result was very similar to that found when considering nitrate supply. Thus, the direct effect of temperature on phytoplankton community structure should be studied through observations in regions where temperature and nutrients dissociate; e.g., cold regions with nutrient limitation (iron-limited regions of the Southern Ocean), or warm regions with abundant nutrients (tropical coastal areas affected by continental runoff). In this regard, some studies have demonstrated that resource availability seems to override temperature as a controlling factor of community structure in terms of broad group composition. Iron addition experiments in highnutrient, low-chlorophyll waters (HNLC) of low-, mid- and high-latitude regions consistently showed a dominance by diatoms after iron fertilization, irrespective of temperature (Boyd et al., 2007). A biomass dominance of the community by picocyanobacteria or small nanophytoplankton has been consistently observed when light or nutrients are 

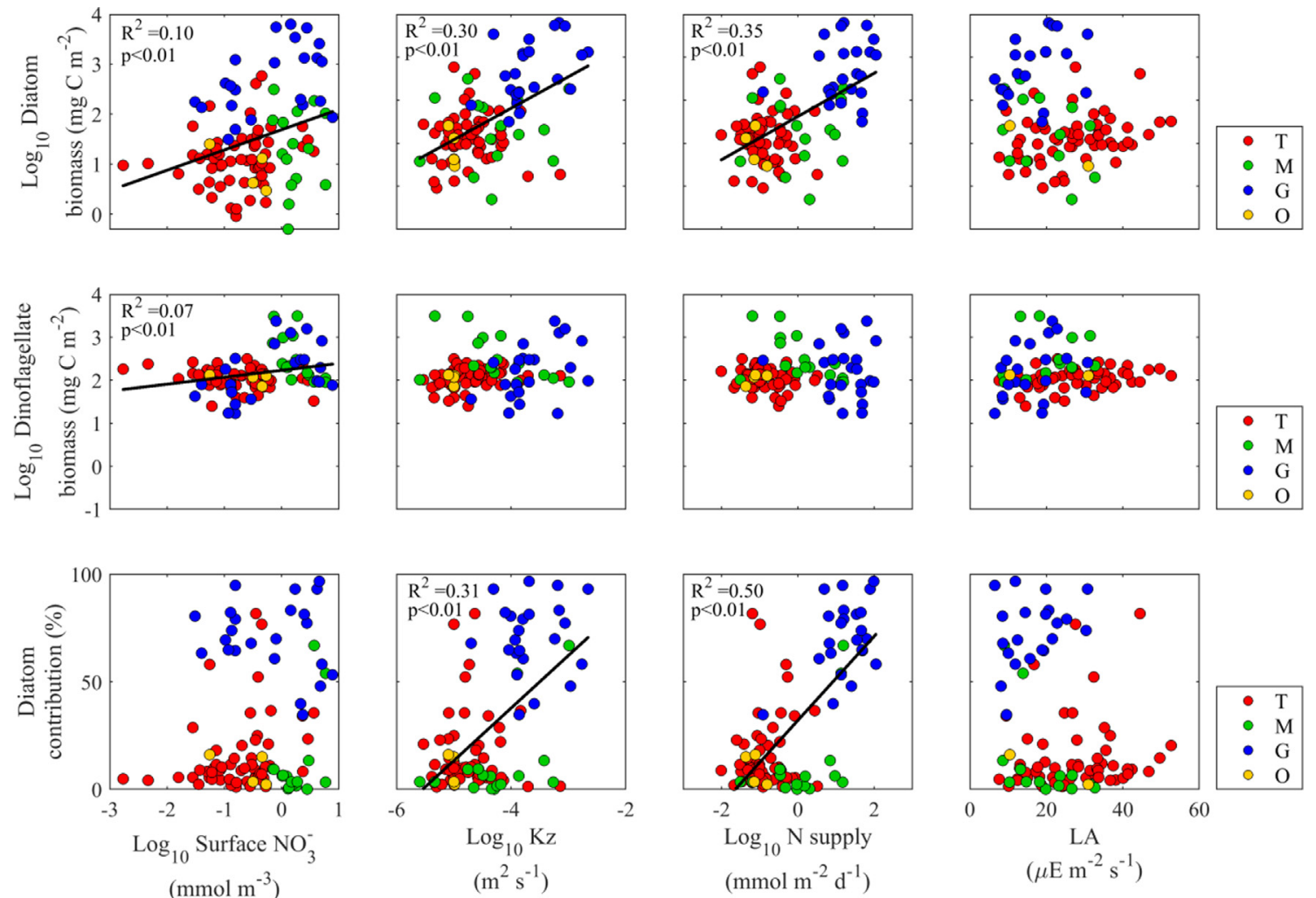

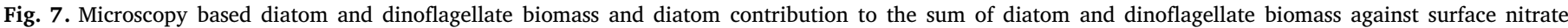

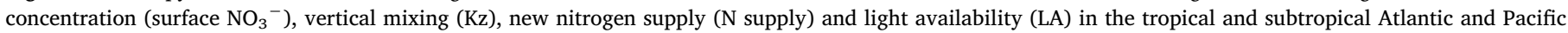

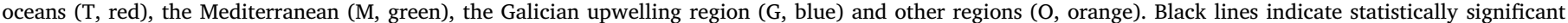

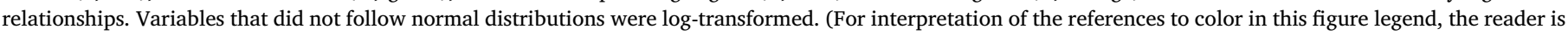
referred to the web version of this article.)

limiting, in warm (Marañón et al., 2012), temperate (Irigoien et al., 2005) and cold (Clarke et al., 2008) waters.

\subsection{Verification of Margalef's mandala}

Our analysis allows us to verify the Margalef's mandala for the whole phytoplankton community using field microstructure turbulence data. Our results show that diatoms predominate in a wider range of mixing than proposed by Margalef $\left(2-100 \mathrm{~cm}^{2} \mathrm{~s}^{-1}\right)$. In the range considered for dinoflagellates $\left(0.02-1 \mathrm{~cm}^{2} \mathrm{~s}^{-1}\right)$, this group presented higher biomass than diatoms based on microscopy results, whereas pigment results showed that cyanobacteria dominated the community.

Margalef chose nutrient concentration and turbulence as principal factors for the selection of phytoplankton "life-forms" because they are related to the supply of external energy (Margalef, 1978). Due to the methodological limitations for quantifying microstructure turbulence in the field, indirect estimates have been traditionally used as a proxy for mixing and nutrient supply. Stratification has been frequently used as equivalent for mixing when investigating the role of environmental factors on phytoplankton communities (Bouman et al., 2011; Jones and Gowen, 1990). However, stratification and mixing are not the same from a physical perspective neither in their effects on phytoplankton communities. Increases in mixing and nutrient supply can occur in stratified water columns due to, for example, internal wave activity (Sharples et al., 2009, 2007; Villamaña et al., 2017). The depth of the mixed layer (Irwin et al., 2012) or the nutricline (Cermeño et al., 2008) have also been used as proxies for the mixing intensity. However, the mixed layer depth derived from temperature or density gradients is a poor indicator of the depth or intensity of active turbulence, which is highly variable over temporal and spatial scales (Franks, 2014). Nutrient concentration, rather than nutrient supply, is commonly considered to evaluate the effect of inorganic nutrients on phytoplankton. But nutrient concentration does not necessarily inform about nutrient availability, since low concentrations can be the result of phytoplankton consumption. This process can be significant in tropical and subtropical regions, where nutrient supply into the euphotic zone is low and phytoplankton uptake maintains nutrient concentration close to the detection limit. For this reason, nitrate concentrations and nitrate supply into the euphotic zone in oligotrophic regions are often disconnected (Mouriño-Carballido et al., 2016, Otero-Ferrer et al., 2018). Our study indicated that new nitrogen supply was more important than nitrate concentration as a factor defining the environmental overlap of the different investigated phytoplankton groups. For this reason, in our verification of the mandala, new nitrogen supply substitutes nutrient concentration in the y-axis, whereas vertical diffusivity derived from observations of microturbulence was placed in the $\mathrm{x}$-axis.

The original Margalef's was conceived before it was widely appreciated that the microbial loop dominate the oligotrophic ocean (Cullen et al., 2002). Moreover, some important additional features and processes revealed in our dataset were not considered. For example, two points of diatom dominance in Chl- $a$ (Fig. 8A) and $>75 \%$ of diatom contribution (Fig. 8C) that were found at low mixing and intermediatehigh new nitrogen supply conditions (dinoflagellates region) correspond to stations sampled in the Galician upwelling region in spring. Special aggregations of phytoplankton, known as thin layers, were detected in these stations at depths of the water column where mixing was low (Fig. 9). The criteria for the detection of thin layers proposed by Sullivan et al. (2010) was met in more than $75 \%$ of the chlorophyll- $a$ vertical profiles sampled on both stations. Several physical and biological mechanisms have been proposed to explain the formation and persistence of phytoplankton thin layers (Durham and Stocker, 2012), but the depths at which they occur are frequently correlated with strong 
A : HPLC-pigments based

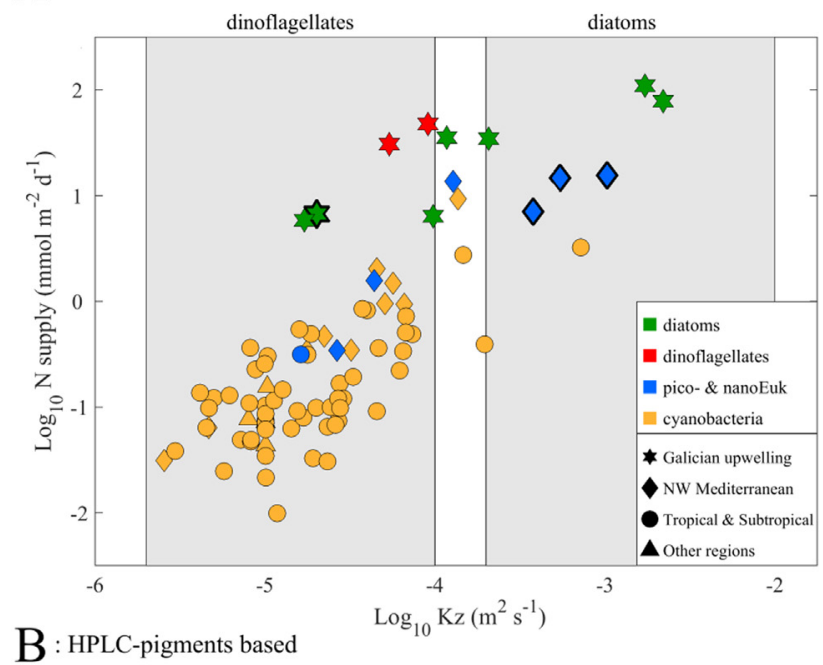

B : HPLC-pigments based
dinoflagellates

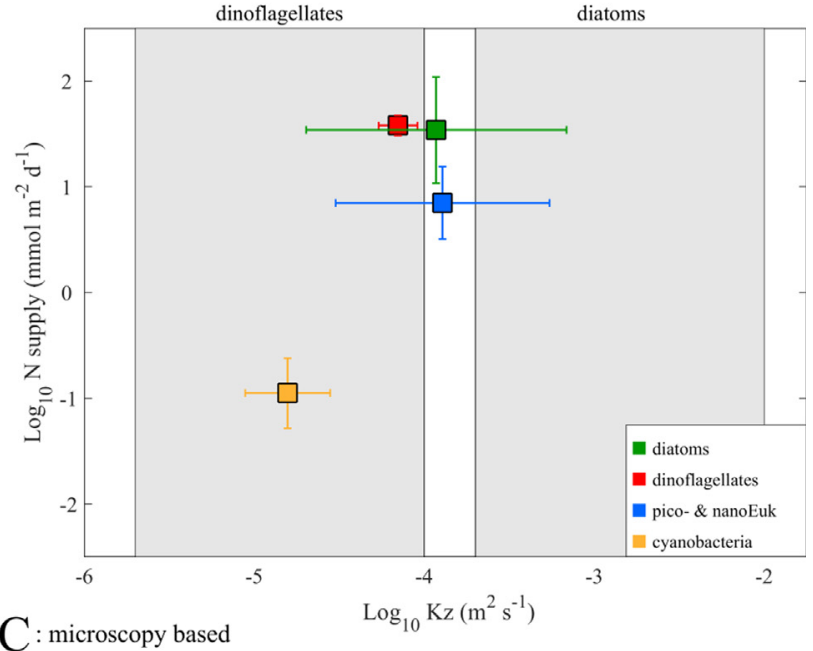

C: microscopy based

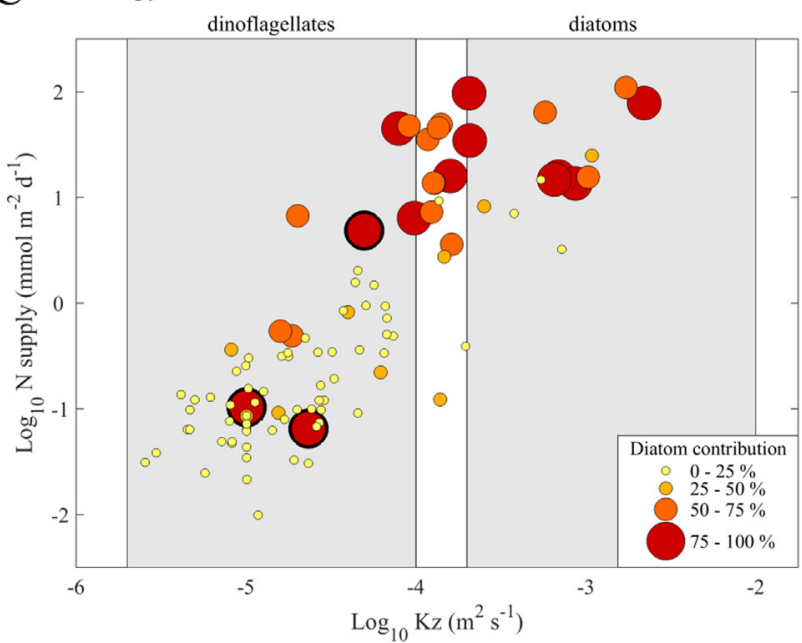

gradients in density (stratification) and vertical shear (Johnston and Rudnick, 2009).

Fig. 8A indicates that three points of pico- and nanoeukaryote dominance were observed at high mixing and high new nitrogen supply levels (diatoms region). These stations were sampled at the northwestern Mediterranean in winter, when intense and deep mixing of the water column was observed (Mouriño-Carballido et al., 2016). In this situation, the phytoplankton cells move rapidly through the water
Fig. 8. (A) Dominance (i.e. the group representing the largest contribution to total chlorophyll- $a$ derived from HPLC-pigments) of diatoms (green), dinoflagellates (red), pico- and nano eukaryotes (blue) and cyanobacteria (yellow) in Galician upwelling region (stars), the Mediterranean (diamonds), tropical and subtropical regions (circles) and other regions (triangles) versus vertical mixing (Kz, $\mathrm{x}$-axis) and new nitrogen supply ( $\mathrm{N}$ supply, $\mathrm{y}$-axis). (B) Median and error bars of vertical mixing (Kz, $\mathrm{x}$-axis) and new nitrogen supply (N supply, $\mathrm{y}$ axis) for diatoms (green), dinoflagellates (red), pico- and nano eukaryotes (blue) and cyanobacteria (yellow) based on their dominance derived from HPLC-pigments. (C) Contribution of diatoms to the sum of diatom and dinoflagellate biomass (derived from microscopy) versus vertical mixing (Kz, $x$-axis) and new nitrogen supply ( $\mathrm{N}$ supply, $y$-axis). Regions in grey color indicate the domains defined by the original Margalef́s model (Margalef, 1978) for diatoms and dinoflagellates based on the magnitude of mixing. Symbols delineated by a thick line indicate exceptions to the general trend: diatom dominance when forming thin layers at low mixing conditions (panels A and $\mathrm{C}$ ); pico- and nanoeukaryotes dominance under high mixing and light limitation conditions (A); and high diatom contribution coinciding with the occurrence of diatoms in symbiotic association with $\mathrm{N}_{2}$-fixing cyanobacteria (C). (For interpretation of the references to color in this figure legend, the reader is referred to the web version of this article.)

column, reaching dark zones where they may not receive enough light (Sverdrup, 1953). Under light-limited conditions, phytoplankton generally increase their intracellular chlorophyll- $a$ concentration (Finkel et al., 2004). Large cells suffer more strongly from 'the package effect' (self-shading between pigments within the cell; Raven, 1998) than smaller cells, and this effect is accentuated when intracellular chlorophyll levels are high (Cermeño et al., 2005; Marañón, 2015). This could explain the dominance of pico- and nanoeukaryotes in the Mediterranean in winter, under high mixing and high new nitrogen supply conditions, since larger cells would be disfavored because of the light limitation.

Finally in Fig. 8C two points of high diatom contribution are remarkable at conditions of low mixing and low new nitrogen supply (dinoflagellates region). These stations were sampled in the South Atlantic and the Indian Subtropical Gyres during the Malaspina expedition and showed high abundance of the diatom Hemiaulus hauckii and substantial $\mathrm{N}_{2}$ fixation activity. Diatoms of the genera Hemiaulus and Rhizosolenia typically form symbiotic associations with Richelia intracellularis, a diazotrophic cyanobacterium. Thus, these regions can gain nutrients, at least nitrogen, even if turbulent mixing is low. These stations were not characterized as diatom dominance in pigment-based Chl- $a$ estimations (Fig. 8A) because, although diatoms presented higher biomass over dinoflagellates, they did not dominate the community. Both the symbiosis with nitrogen-fixing cyanobacteria and the formation of thin layers allow diatoms to grow under low mixing conditions, such as those characterizing the subtropical gyres or density interfaces in coastal regions (Kemp and Villareal, 2018). In fact, in the original model, Margalef $(1967,1978)$ already considered the ecological plasticity across diatoms and placed the genera Rhizosolenia in an intermediate part of his mandala. However, as recently emphasized by Kemp and Villareal (2018), most ocean biogeochemical models have simplified the original mandala and consider diatoms as a single functional type that thrives in high turbulence and high nutrients waters. It is therefore important to consider the ability of certain diatom species to grow in stratified waters in order to predict the response of phytoplankton communities to future scenarios of increased ocean stratification.

\section{Conclusions}

The development of commercial microstructure turbulence profilers allowed to quantify dissipation rates of turbulent kinetic energy in the field, which are essential to investigate the role of light and nutrient availability for phytoplankton cells. This progress improved significantly our understanding of the factors that control phytoplankton 


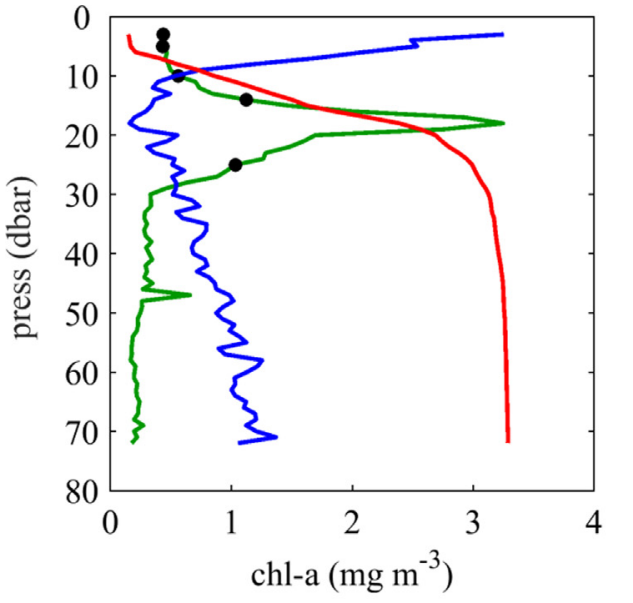

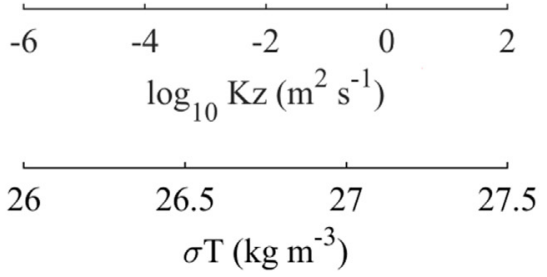

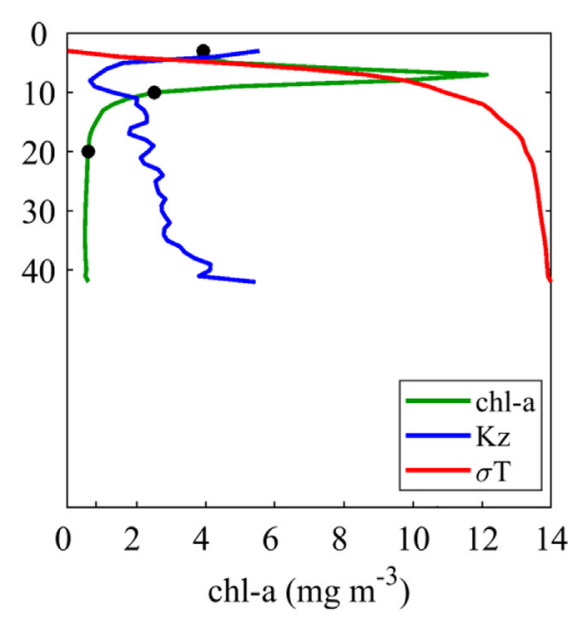

Fig. 9. Averaged vertical distribution of chlorophyll- $a$ (Chl- $a$ ), vertical mixing (Kz) and sigma-t $(\sigma \mathrm{T})$ in two stations sampled in the shelf (ASIMUTH, $42.149^{\circ} \mathrm{N}-8.921^{\circ} \mathrm{W}$, left, $\mathrm{n}=5$ ) and the inner part (DISTRAL, $42.236^{\circ} \mathrm{N}-8.788^{\circ} \mathrm{W}$, right, $\mathrm{n}=75$ ) of Ría de Vigo on $18 / 06 / 2013$ and $14 / 05 / 2012$, respectively. Black dots indicate the sample depths for HPLC-pigments (ASIMUTH) and microscopy (DISTRAL). $n$ is the number of vertical profiles carried out with the microstructure turbulence profiler at each station.

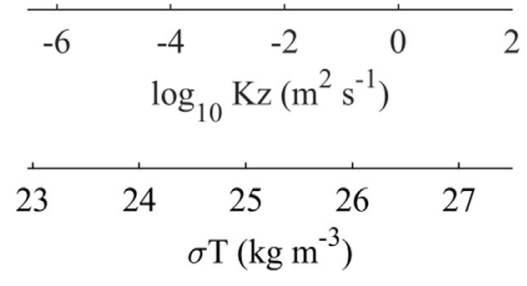

community structure, and opened the possibility to revisit classical models of phytoplankton ecology. The present study expands Margalef's mandala to encompass the whole phytoplankton community in the field and uses direct measurements of microstructure turbulence to quantify nitrate supply and light availability. Our results reveal that mixing and new nitrogen supply are the main factors controlling the phytoplankton community structure and highlight the need to consider nutrient supply, instead of nutrient concentration, as an indicator of nutrient availability for phytoplankton cells. We found that at lower values of mixing and new nitrogen supply cyanobacteria dominated, pico- and nanoeukaryotes were dominant across a wide range of these environmental conditions, and enhanced new nitrogen supply was favorable for diatoms and dinoflagellates. However, whereas dinoflagellates were prevalent at intermediate mixing levels, diatoms spread across a wider range of mixing conditions. Moreover, some features revealed by our dataset, such as the role of $\mathrm{N}_{2}$ fixation and thin phytoplankton layers extend the applicability of the mandala beyond its original formulation. Future global change scenarios predict an increase in ocean stratification, so it is important to consider the ability of diatoms to reach elevated abundances also in stratified waters. Understanding the role of mixing as a driver of phytoplankton community structure and composition is essential in order to predict the future functioning of aquatic ecosystems.

\section{Acknowledgements}

We are grateful to all the technicians, researchers and crew on board the R/V Hespérides, Sarmiento de Gamboa, Mytilus and Ramón Margalef for their help during field work. We also thank P. Chouciño for microstructure turbulence data collection and processing, and T. Wyatt for valuable comments on the manuscript. This research was funded by projects: CHAOS (CTM2012-30680) and REMEDIOS (CTM2016-75451C2-1-R) to B. Mouriño-Carballido, DISTRAL (CTM2011-25035) to P. Cermeño, REIMAGE (CTM2011-30155-C03-01) to E. Fernández, FAMOSO (CTM2008-06261-C03) to M. Latasa and Malaspina (CSD2008-00077) to C. Duarte from the Spanish Ministry of Economy and Competitiveness. ASIMUTH (FP7 SPACE.2010.1.1-01 \#261860) grant to M. Ruiz-Villareal was supported by the 7th Framework Programme of the European Commission. M. Villamaña acknowledges the receipt of a FPU fellowship (FPU014/05385) from the Spanish Ministry of Education, Culture and Sports.

\section{References}

Agawin, N.S.R., Duarte, C.M., Agusti, S., 2000. Nutrient and temperature control of the contribution of picoplankton to phytoplankton biomass and production. Limnology 45, 591-600. Published by: American Society of Limnology and Oceanography Stable URL: http://www.jstor.org/stable/2670836.

Álvarez-Salgado, X.A., Beloso, S., Joint, I., Nogueira, E., Chou, L., Perez, F.F., Groom, S., Cabanas, J.M., Rees, A.P., Elskens, M., 2002. New production of the NW Iberian shelf during the upwelling season over the period 1982-1999. Deep. Res. Part I Oceanogr. Res. Pap. 49, 1725-1739. https://doi.org/10.1016/S0967-0637(02)00094-8.

Álvarez-Salgado, X.A., Figueiras, F.G., Pérez, F.F., Groom, S., Nogueira, E., Borges, A., Chou, L., Castro, C.G., Moncoiffé, G., Ríos, A.F., Miller, A.E., Frankignoulle, M. Savidge, G., Wollast, R., 2003. The Portugal coastal counter current off NW Spain: new insights on its biogeochemical variability. Prog. Oceanogr. 56, 281-321. https:// doi.org/10.1016/S0079-6611(03)00007-7.

Álvarez-Salgado, X.A., Rosón, G., Pérez, F.F., Pazos, Y., Álvarez-Salgado, X.A., Rosón, G., Perez, F.F., Figueiras, F.G., Pazos, Y., 1993. Hydrographic variability off the Rías Baixas (NW Spain) during the upwelling season. J. Geophys. Res. 98, 14447-14455. https://doi.org/10.1029/93JC00458.

Arístegui, J., Barton, E.D., Álvarez-Salgado, X.A., Santos, A.M.P., Figueiras, F.G., Kifani, S., Hernández-León, S., Mason, E., Machú, E., Demarcq, H., 2009. Sub-regional ecosystem variability in the Canary Current upwelling. Prog. Oceanogr. 83, 33-48. https://doi.org/10.1016/j.pocean.2009.07.031.

Arrigo, K.R., 2005. Molecular diversity and ecology of microbial plankton. Nature 437, 343-348. https://doi.org/10.1038/nature04158.

Ausín, B., Zúñiga, D., Flores, J.A., Cavaleiro, C., Froján, M., Villacieros-Robineau, N., Alonso-Pérez, F., Arbones, B., Santos, C., De La Granda, F., Castro, C.G., Abrantes, F., Eglinton, T.I., Salgueiro, E., 2018. Spatial and temporal variability in coccolithophore abundance and distribution in the NW Iberian coastal upwelling system. Biogeosciences 15, 245-262. https://doi.org/10.5194/bg-15-245-2018.

Barton, A.D., Lozier, M.S., Williams, R.G., 2015. Physical controls of variability in north Atlantic phytoplankton communities. Limnol. Oceanogr. 60, 181-197. https://doi org/10.1002/lno.10011.

Berdalet, E., Peters, F., Koumandou, V.L., Roldán, C., Guadayol, Ò., Estrada, M., 2007. Species-specific physiological response of dinoflagellates to quantified small-scale turbulence. J. Phycol. 43, 965-977. https://doi.org/10.1111/j.1529-8817.2007. 00392.x.

Bouman, H.A., Ulloa, O., Barlow, R., Li, W.K.W., Platt, T., Zwirglmaier, K., Scanlan, D.J., Sathyendranath, S., 2011. Water-column stratification governs the community structure of subtropical marine picophytoplankton. Environ. Microbiol. Rep. 3, 473-482. https://doi.org/10.1111/j.1758-2229.2011.00241.x.

Bowman, M.J., Wayne, E.E., Schnitzer, M.B., 1981. Tidal stirring and the distribution of phytoplankon in Long Island and Block Island Sounds. J. Geophys. Res. 39, 587-603.

Boyd, P.W., Jickells, T., Law, C.S., Blain, S., Boyle, E.A., Buesseler, K.O., Coale, K.H., Cullen, J.J., de Baar, H.J.W., Follows, M., Harvey, M., Lancelot, C., Levasseur, M., Owens, N.P.J., Pollard, R., Rivkin, R.B., Sarmiento, J., Schoemann, V., Smetacek, V., Takeda, S., Tsuda, A., Turner, S., Watson, A.J., 2007. Mesoscale iron enrichment 
experiments 1993-2005: synthesis and future directions. Science 315 (5812), 612-617. http://www.sciencemag.org/cgi/doi/10.1126/science:1131669https:// doi.org/10.1126/science:1131669.

Brun, P., Vogt, M., Payne, M.R., Gruber, N., O’Brien, C.J., Buitenhuis, E.T., Le Quéré, C., Leblanc, K., Luo, Y.W., 2015. Ecological niches of open ocean phytoplankton taxa. Limnol. Oceanogr. 60, 1020-1038. https://doi.org/10.1002/lno.10074.

Capone, D.G., Burns, J.A., Montoya, J.P., Subramaniam, A., Mahaffey, C., Gunderson, T., Michaels, A.F., Carpenter, E.J., 2005. Nitrogen fixation by Trichodesmium spp.: an important source of new nitrogen to the tropical and subtropical North Atlantic Ocean. Global Biogeochem. Cycl. 19, 1-17. https://doi.org/10.1029/ 2004GB002331.

Cermeño, P., Chouciño, P., Fernández-Castro, B., Figueiras, F.G., Marañón, E., Marrasé, C., Mouriño-Carballido, B., Pérez-Lorenzo, M., Rodríguez-Ramos, T., Teixeira, I., Vallina, S.M., 2016. Marine primary productivity is driven by a selection effect. Front. Mar. Sci. 3, 173. https://doi.org/10.3389/fmars.2016.00173.

Cermeño, P., Dutkiewicz, S., Harris, R.P., Follows, M.J., Schofield, O., Falkowski, P.G., 2008. The role of nutricline depth in regulating the ocean carbon cycle. Proc. Natl. Acad. Sci. 105, 20344-20349. https://doi.org/10.1073/pnas.0811302106.

Cermeño, P., Lee, J.-B., Wyman, K., Schofield, O., Falkowski, P.G., 2011. Competitive dynamics in two species of marine phytoplankton under non-equilibrium conditions. Mar. Ecol. Prog. Ser. 429, 19-28. https://doi.org/10.3354/meps09088.

Cermeño, P., Marañón, E., Rodríguez, J., Fernández, E., 2005. Size dependence of coastal phytoplankton photosynthesis under vertical mixing conditions. J. Plank. Res. 27, 473-483. https://doi.org/10.1093/plankt/fbi021.

Chisholm, S.W., 1992. Phytoplankton size. In: Primary Productivity and Biogeochemical Cycles in the Sea, pp. 213-237. https://doi.org/10.1007/978-1-4899-0762-2 12.

Clarke, A., Meredith, M.P., Wallace, M.I., Brandon, M.A., Thomas, D.N., 2008. Seasonal and interannual variability in temperature, chlorophyll and macronutrients in northern Marguerite Bay, Antarctica. Deep. Res. Part II Top. Stud. Oceanogr. 55, 1988-2006. https://doi.org/10.1016/j.dsr2.2008.04.035.

Cullen, J.J., Franks, P.J.S., Karl, D.M., Longhurst, A.R., 2002. Physical influences on marine ecosystem dynamics. In: Robinson, A.R., McCarthy, J.J., Rotchschild, B.J. (Eds.), The Sea. John Wiley \& Sons, New York, pp. 297-336.

Cullen, J.J., MacIntyre, J.G., 1998. Behavior, physiology and the niche of depth-regulating phytoplankton. Physiol. Ecol. Harmf. Algal Bloom. 41, 559-580.

Díaz, P.A., Ruiz-Villarreal, M., Rodríguez, F., Luis, J., Mouriño-Carballido, B., FernándezPena, C., Riobó, P., Reguera, B., 2019. Fine scale physical-biological interactions during a shift from relaxation to upwelling with a focus on Dinophysis acuminata and its potential ciliate prey. Prog. Oceanogr. https://doi.org/10.1016/j.pocean.2019.04. 009.

Dugdale, R.C., Goering, J.J., 1987. Uptake of new and regenerated forms of nitrogen in primary productivity. Limnol. Oceanogr. 196-206.

Durham, W.M., Stocker, R., 2012. Thin phytoplankton layers: characteristics, mechanisms, and consequences. Ann. Rev. Mar. Sci. 4, 177-207. https://doi.org/10.1146/ annurev-marine-120710-100957.

Estrada, M., Alcaraz, M., Marrasé, C., 1988. Effects of turbulence on the development of phytoplankton biomass and copepod populations in marine microcosms. Mar. Ecol. Prog. Ser. 49, 117-125. https://doi.org/10.3354/meps049117.

Estrada, M., Berdalet, E., 1996. Phytoplankton in a turbulent world. Sci. Mar. 61, 125-140.

Estrada, M., Delgado, M., Blasco, D., Latasa, M., Cabello, A.M., Benítez-Barrios, V.M., Fraile-Nuez, E., Mozetič, P., Vidal, M., 2016. Phytoplankton across tropical and subtropical regions of the Atlantic, Indian and Pacific Oceans. PLoS One 11, e0151699. https://doi.org/10.1371/journal.pone.0151699.

Estrada, M., Latasa, M., Emelianov, M., Gutiérrez-Rodríguez, A., Fernández-Castro, B., Isern-Fontanet, J., Mouriño-Carballido, B., Salat, J., Vidal, M., 2014. Seasonal and mesoscale variability of primary production in the deep winter-mixing region of the NW Mediterranean. Deep. Res. Part I Oceanogr. Res. Pap. 94, 45-61. https://doi.org/ 10.1016/j.dsr.2014.08.003.

Falkowski, P.G., 2012. Ocean science: the power of plankton. Nature 483, S17-S20. https://doi.org/10.1038/483S17a.

Falkowski, P.G., Barber, R.T., Smetacek, V., 1998. Production biogeochemical controls and feedbacks on ocean primary biogeochemical controls and feedbacks on ocean primary production. Science (80-.) 200, 200-207. https://doi.org/10.1126/science 281.5374.200.

Falkowski, P.G., Oliver, M.J., 2007. Mix and match: how climate selects phytoplankton. Nat. Rev. Microbiol. 5 (10), 813-819.

Fernández-Castro, B., Gilcoto, M., Naveira-Garabato, A.C.A.C., Graña, R., MouriñoCarballido, B., Villamaña, M., Graña, R., Mouriño-Carballido, B., 2018. Modulation of the semidiurnal cycle of turbulent dissipation by wind-driven upwelling in a coastal embayment. J. Geophys. Res. Ocean. 123, 1-21. https://doi.org/10.1002/ 2017JC013582

Fernández-Castro, B., Mouriño-Carballido, B., Benítez-Barrios, V.M., Chouciño, P., FraileNuez, E., Graña, R., Piedeleu, M., Rodríguez-Santana, Á., 2014. Microstructure turbulence and diffusivity parameterization in the tropical and subtropical Atlantic, Pacific and Indian Oceans during the Malaspina 2010 expedition. Deep. Sea Res. Part I Oceanogr. Res. Pap. 94, 15-30. https://doi.org/10.1016/j.dsr.2014.08.006.

Fernández-Castro, B., Mouriño-Carballido, B., Marañón, E., Chouciño, P., Gago, J., Ramírez, T., Vidal, M., Bode, A., Blasco, D., Royer, S.-J., Estrada, M., Simó, R., 2015. Importance of salt fingering for new nitrogen supply in the oligotrophic ocean. Nat. Commun. 6, 1-10. https://doi.org/10.1038/ncomms9002.

Fernández, E., Álvarez-Salgado, X.A., Beiras, R., Ovejero, A., Méndez, G., 2016. Coexistence of urban uses and shellfish production in an upwelling-driven, highly productive marine environment: the case of the Ría de Vigo (Galicia, Spain). Reg. Stud. Mar. Sci. 8, 362-370. https://doi.org/10.1016/j.rsma.2016.04.002.

Field, C.B., Behrenfeld, M.J., Randerson, J.T., Falkowski, P.G., 1998. Primary production of the biosphere: integrating terrestrial and oceanic components. Science (80-.) 281, 237-240. https://doi.org/10.1126/science.281.5374.237.

Finkel, Z.V., Irwin, A.J., Schofield, O., 2004. Resource limitation alters the $3 / 4$ size scaling of metabolic rates in phytoplankton. Mar. Ecol. Prog. Ser. 273, 269-279. https://doi.org/10.3354/meps273269.

Franks, P.J.S., 2014. Has Sverdrup's critical depth hypothesis been tested? Mixed layers vs. turbulent layers. ICES J. Mar. Sci. 72, 1897-1907. https://doi.org/10.1093/ icesjms/fsu175.

Geange, S.W., Pledger, S., Burns, K.C., Shima, J.S., 2011. A unified analysis of niche overlap incorporating data of different types. Meth. Ecol. Evol. 2, 175-184. https:// doi.org/10.1111/j.2041-210X.2010.00070.x.

Glibert, P.M., 2016. Margalef revisited: a new phytoplankton mandala incorporating twelve dimensions, including nutritional physiology. Harmf. Algae 55, 25-30. https://doi.org/10.1016/j.hal.2016.01.008.

Glibert, P.M., Wilkerson, F.P., Dugdale, R.C., Raven, J.A., Dupont, C.L., Leavitt, P.R., Parker, A.E., Burkholder, J.M., Kana, T.M., 2016. Pluses and minuses of ammonium and nitrate uptake and assimilation by phytoplankton and implications for productivity and community composition, with emphasis on nitrogen-enriched conditions. Limnol. Oceanogr. 61, 165-197. https://doi.org/10.1002/lno.10203.

Grasshoff, K., Kremling, K., Ehrhardt, M., 2007. Methods of Seawater Analysis: Third, Completely Revised and Extended Edition. https://doi.org/10.1002/ 9783527613984.

Guadayol, O., Peters, F., Stiansen, J.E., Marrasé, C., Lohrmann, A., 2009. Evaluation of oscillating grids and orbital shakers as means to generate isotropic and homogeneous small-scale turbulence in laboratory enclosures commonly used in plankton studies. Limnol. Oceanogr. Meth. 7, 287-303. https://doi.org/10.4319/lom.2009.7.287.

Harrison, P.J., Zingone, A., Mickelson, M.J., Lehtinen, S., Ramaiah, N., Kraberg, A.C., Sun, J., McQuatters-Gollop, A., Jakobsen, H.H., 2015. Cell volumes of marine phytoplankton from globally distributed coastal data sets. Estuar. Coast. Shelf Sci. 162, 130-142. https://doi.org/10.1016/j.ecss.2015.05.026.

Hillebrand, H., Dürselen, C.-D., Kirschtel, D., Pollingher, U., Zohary, T., 1999. Biovolume calculation for pelagic and benthic microalgae. J. Phycol. 424, 403-424. https://doi. org/10.1046/j.1529-8817.1999.3520403.x.

Hilligsøe, K.M., Richardson, K., Bendtsen, J., Sørensen, L.L., Nielsen, T.G., Lyngsgaard, M.M., 2011. Linking phytoplankton community size composition with temperature, plankton food web structure and sea-air CO2flux. Deep. Res. Part I Oceanogr. Res. Pap. 58, 826-838. https://doi.org/10.1016/j.dsr.2011.06.004.

Irigoien, X., Flynn, K.J., Harris, R.P., 2005. Phytoplankton blooms: A "loophole" in microzooplankton grazing impact? J. Plank. Res. 27, 313-321. https://doi.org/10. 1093/plankt/fbi011.

Irwin, A.J., Nelles, A.M., Finkel, Z.V., 2012. Phytoplankton niches estimated from field data. Limnol. Oceanogr. 57, 787-797. https://doi.org/10.4319/10.2012.57.3.0787.

Johnston, T.M.S., Rudnick, D.L., 2009. Observations of the transition layer. J. Phys. Oceanogr. 39, 780-797. https://doi.org/10.1175/2008JPO3824.1.

Jones, D.L., 2015. Fathom Toolbox for Matlab: software for multivariate ecological and oceanographic data analysis.

Jones, K.J., Gowen, R.J., 1990. Influence of stratification and irradiance regime on summer phytoplankton composition in coastal and shelf seas of the British Isles. Estuar. Coast. Shelf Sci. 30, 557-567. https://doi.org/10.1016/0272-7714(90) 90092-6.

Kamykowski, D., Zentara, S., 1986. Predicting plant nutrient concentrations from temperature and sigma- $£$ in the upper kilometer of the world ocean. Deep. Res. 33, 89-105.

Kemp, A.E.S., Villareal, T.A., 2018. The case of the diatoms and the muddled mandalas: time to recognize diatom adaptations to stratified waters. Prog. Oceanogr. 167 138-149. https://doi.org/10.1016/j.pocean.2018.08.002.

Kiørboe, T., 1993. Turbulence, phytoplankton cell size, and the structure of pelagic food webs. Adv. Mar. Biol. 29, 1-72. https://doi.org/10.1016/S0065-2881(08)60129-7.

Kirk, J.T.O., 1994. Light and Photosynthesis in Aquatic Ecosystems, third ed. Cambridge University Press, Cambridge.

Large, W.G., McWilliams, J.C., Doney, S.C., 1994. Oceanic vertical mixing: a review and a model with a nonlocal boundary layer parameterization. Rev. Geophys. 32, 363-403. https://doi.org/10.1029/94rg01872.

Latasa, M., 2007. Improving estimations of phytoplankton class abundances using CHEMTAX. Mar. Ecol. Prog. Ser. 329, 13-21. https://doi.org/10.3354/meps329013.

Legendre, L., Rassoulzadegan, F., 1995. Plankton and nutrient dynamics in marine waters. Ophelia 41, 153-172. https://doi.org/10.1080/00785236.1995.10422042.

Letelier, R.M., Bidigare, R.R., Hebel, D.V., Ondrusek, M., Winn, C.D., Karl, D.M., 1993. Temporal variability of phytoplankton community structure based on pigment analysis. Limnol. Oceanogr. 38, 1420-1437. https://doi.org/10.4319/lo.1993.38.7. 1420 .

Litchman, E., 2007. Resource competition and the ecological success of phytoplankton. Evol. Prim. Prod. Sea 351-375. https://doi.org/10.1016/B978-012370518-1/ 50017-5.

Lomas, M.W., Glibert, P.M., 1999a. Interactions between NH4/+ and NO3/- uptake and assimilation: comparison of diatoms and dinoflagellates at several growth temperatures. Mar. Biol. 133, 541-551. https://doi.org/10.1007/s002270050494.

Lomas, M.W., Glibert, P.M., 1999b. Temperature regulation of nitrate uptake: a novel hypothesis about nitrate uptake and in cool-water reduction diatoms. Limnol. Oceanogr. 44, 556-572.

Machado, D.A., Marti, C.L., Imberger, J., 2014. Influence of microscale turbulence on the phytoplankton of a temperate coastal embayment, Western Australia. Estuar. Coast. Shelf Sci. 145, 80-95. https://doi.org/10.1016/j.ecss.2014.04.018.

Marañón, E., 2015. Cell size as a key determinant of phytoplankton metabolism and community structure. Ann. Rev. Mar. Sci. 7, 241-264. https://doi.org/10.1146/ annurev-marine-010814-015955. 
Marañón, E., Cermeño, P., Latasa, M., Tadonléké, R.D., 2012. Temperature, resources, and phytoplankton size structure in the ocean. Limnol. Oceanogr. 57, 1266-1278. https://doi.org/10.4319/10.2012.57.5.1266.

Margalef, R., 1994. Through the looking glass: how marine phytoplankton appears through the microscope when graded by size and taxonomically sorted. Sci. Mar. 58, 87-101.

Margalef, R., 1978. Life-forms of phytoplankton as survival alternatives in an unstable environment. Oceanol. Acta 1, 493-509.

Margalef, R., 1967. The food web in the pelagic environment. Helgoländer Wissenschaftliche Meeresuntersuchungen 15, 548-559. https://doi.org/10.1007/ BF01618650.

McDougall, T.J., Ruddick, B.R., 1992. The use of ocean microstructure to quantify both turbulent mixing and salt-fingering. Deep. Sea Res. Part A, Oceanogr. Res. Pap. 39, 1931-1952. https://doi.org/10.1016/0198-0149(92)90006-F.

Menden-Deuer, S., Lessard, E.J., 2000. Carbon to volume relationships for dinoflagellates, diatoms, and other protist plankton. Limnol. Oceanogr. 45, 569-579. https://doi.org/ 10.4319/lo.2000.45.3.0569.

Montoya, J.P., Voss, M., Kahler, P., Capone, D.G., 1996. A simple, high-precision, highsensitivity tracer assay for N2 fixation. Appl. Environ. Microbiol. 62, 986-993.

Morán, X.A.G., López-Urrutia, Á., Calvo-Díaz, A., Li, W.K.W., 2010. Increasing importance of small phytoplankton in a warmer ocean. Glob. Chang. Biol. 16, 1137-1144. https://doi.org/10.1111/j.1365-2486.2009.01960.x.

Mouillot, D., Stubbs, W., Faure, M., Dumay, O., Tomasini, J.A., Wilson, J.B., Chi, T. Do, 2005. Niche overlap estimates based on quantitative functional traits: a new family of non-parametric indices. Oecologia 145, 345-353. https://doi.org/10.1007/s00442005-0151-z.

Mouriño-Carballido, B., Graña, R., Fernández, A., Bode, A., Varela, M., Domínguez, J.F., Escánez, J., de Armas, D., Marañón, E., 2011. Importance of N2 fixation vs. nitrate eddy diffusion along a latitudinal transect in the Atlantic Ocean. Limnol. Oceanogr. 56, 999-1007. https://doi.org/10.4319/lo.2011.56.3.0999.

Mouriño-Carballido, B., Hojas, E., Cermeño, P., Chouciño, P., Fernández-Castro, B. Latasa, M., Marañón, E., Morán, X.A.G., Vidal, M., 2016. Nutrient supply controls picoplankton community structure during three contrasting seasons in the northwestern Mediterranean Sea. Mar. Ecol. Prog. Ser. 543, 1-19. https://doi.org/10. 3354/meps11558.

Osborn, T.R., 1980. Estimates of the local rate of vertical diffusion from dissipation measurements. Oceanography 10, 83-89. https://doi.org/10.1175/1520-0485(1980) $010<0083$ : eotlro $>2.0$. co; 2

Otero-Ferrer, J.L., Cermeño, P., Fernández-Castro, B., Gasol, J.M., Morán, X.A.G., Marañón, E., Moreira-Coello, V., Varela, M., Villamaña, M., Mouriño-Carballido, B., 2018. Factors controlling the community structure of picoplankton in contrasting marine environments. Biogeosciences.

Pearman, J.K., Ellis, J., Irigoien, X., Sarma, Y.V.B., Jones, B.H., Carvalho, S., 2017. Microbial planktonic communities in the Red Sea: high levels of spatial and temporal variability shaped by nutrient availability and turbulence. Nat. Sci. Rep. 7, 1-15. https://doi.org/10.1038/s41598-017-06928-z.

Peters, F., Arin, L., Marrasé, C., Berdalet, E., Sala, M.M., 2006. Effects of small-scale turbulence on the growth of two diatoms of different size in a phosphorus-limited medium. J. Mar. Syst. 61, 134-148. https://doi.org/10.1136/thx.2005.049403.

Peters, F., Marrasé, C., 2000. Effects of turbulence on plankton: an overview of experimental evidence and some theoretical considerations. Mar. Ecol. Prog. Ser. 205, 291-306. https://doi.org/10.3354/meps205291.

Peters, F., Redondo, J.M., 1997. Turbulence generation and measurement: application to studies on plankton. Sci. Mar. 61, 205-228. https://doi.org/10.3354/meps06974.

Prairie, J.C., Sutherland, K.R., Nickols, K.J., Kaltenberg, A.M., 2012. Biophysical interactions in the plankton: a cross-scale review. Limnol. Oceanogr. Fluids Environ. 2, 121-145. https://doi.org/10.1215/21573689-1964713.

Prandke, H., Stips, A., 1998. Test measurements with an operational microstructureturbulence profiler: detection limit of dissipation rates. Aquat. Sci. 60, 191-209. https://doi.org/10.1007/s000270050036.

R Development Core Team, 2018. R: A Language and Environment. for Statistical Computing.

Raven, J.A., 1998. The twelfth Tansley Lecture. Small is beautiful: the picophytoplankton. Funct. Ecol. 12, 502-513. https://doi.org/10.1046/j.1365-2435.1998.00233.x.

Reynolds, C.S., 1999. With or against the grain: responses of phytoplankton to pelagic variability. In: Whitfield, M., Matthews, J., Reynolds, C.S. (Eds.), Aquatic Life Cycle Strategies. MBA Occ Publ, pp. 15-43.

Reynolds, C.S., 1987. Community organization in the freshwater plankton. Symp. Br. Ecol. Soc. 27, 297-325.
Richardson, K., Beardall, J., Raven, J.A., 1983. Adaption of unicellular algae to irradiance: an analysis of strategies. New Phytol. 93, 157-191. https://doi.org/10.1111/ j.1469-8137.1983.tb03422.x.

Ross, O.N., Sharples, J., 2004. Recipe for 1-D Lagrangian particle tracking models in space-varying diffusivity. Limnol. Oceanogr. Meth. 2, 289-302. https://doi.org/10. 4319/lom.2004.2.289.

Sal, S., López-Urrutia, Á., Irigoien, X., Harbour, D.S., Harris, R.P., 2013. Marine microplankton diversity database. Ecology 94, 1658. https://doi.org/10.1890/13-0236.1.

Sharples, J., Moore, C.M., Hickman, A.E., Holligan, P.M., Tweddle, J.F., Palmer, M.R., Simpson, J.H., 2009. Internal tidal mixing as a control on continental margin ecosystems. Geophys. Res. Lett. 36, 1-5. https://doi.org/10.1029/2009GL040683.

Sharples, J., Tweddle, J.F., Green, J.A.M., Palmer, M.R., Kim, Y.-N., Hickman, A.E., Holligan, P.M., Moore, C.M., Rippeth, T.P., Simpson, J.H., Krivtsov, V., 2007. Springneap modulation of internal tide mixing and vertical nitrate fluxes at a shelf edge in summer. Limnol. Oceanogr. 52, 1735-1747. https://doi.org/10.4319/lo.2007.52.5. 1735.

Smayda, T.J., 1997. Harmful algal blooms: their ecophysiology and general relevance to phytoplankton blooms in the sea. Limnol. Oceanogr. 42, 1137-1153. https://doi.org/ 10.4319/lo.1997.42.5_part_2.1137.

Smayda, T.J., Reynolds, C.S., 2001. Community assembly in marine phytoplankton: application of recent models to harmful dinoflagellate blooms. J. Plank. Res. 23, 447-461. https://doi.org/10.1093/plankt/23.5.447.

Sommer, U., 1984. The paradox of the plankton: Fluctuations of phosphorus availability maintain diversity of phytoplankton in flow-through cultures. Limnol. Oceanogr. 29, 633-636. https://doi.org/10.4319/lo.1984.29.3.0633.

Sommer, U., Charalampous, E., Genitsaris, S., Moustaka-Gouni, M., 2017. Benefits, costs and taxonomic distribution of marine phytoplankton body size. J. Plank. Res. 39, 494-508. https://doi.org/10.1093/plankt/fbw071.

St. Laurent, L., Schmitt, R.W., 1999. The contribution of salt fingers to vertical mixing in the north atlantic tracer release experiment. J. Phys. Oceanogr. 23, 29-36. https:// doi.org/10.1175/1520-0485(1999) 029<1404:TCOSFT > 2.0.CO;2.

Stevens, C., Smith, M., Ross, A., 1999. SCAMP: measuring turbulence in estuaries, lakes and coastal waters. Water Atmos 7, 20-21.

Stine, R.A., Heyse, J.F., 2001. Non-parametric estimates of overlap. Stat. Med. 20 215-236. https://doi.org/10.1002/1097-0258(20010130)20:2<215::AID SIM642 > 3.0.CO;2-X.

Sullivan, J.M., Donaghay, P.L., Rines, J.E., 2010. Coastal thin layer dynamics: consequences to biology and optics. Cont. Shelf Res. 30, 50-65. https://doi.org/10. 1016/j.csr.2009.07.009.

Sverdrup, H.U., 1953. On conditions for the vernal blooming of phytoplankton. J. du Cons. Int. pour l'Exploration la Mer. 18, 287-295. https://doi.org/10.1093/icesjms/ 18.3.287.

Thorpe, S.A., 2007. An Introduction to Ocean Turbulence. https://doi.org/10.1029/ 2008 EO520011.

Utermöhl, H., 1958. Zur Vervollkommnung der quantitativen Phytoplankton-Methodik. Mitt. Int. Ver. Theor. Angew. Limnol. 9, 1-38. https://doi.org/10.1080/05384680. 1958.11904091.

Vallina, S.M., Simó, R., 2007. Strong relationship between DMS and the solar radiation dose over the global surface ocean. Science 315, 506-508. https://doi.org/10.1126/ science. 1133680 .

Villamaña, M., Mouriño-Carballido, B., Marañón, E., Cermeño, P., Chouciño, P., da Silva, J.C.B., Díaz, P.A., Fernández-Castro, B., Gilcoto, M., Graña, R., Latasa, M., Magalhaes, J.M., Otero-Ferrer, J.L., Reguera, B., Scharek, R., 2017. Role of internal waves on mixing, nutrient supply and phytoplankton community structure during spring and neap tides in the upwelling ecosystem of Ría de Vigo (NW Iberian Peninsula). Limnol. Oceanogr. 62, 1014-1030. https://doi.org/10.1002/lno.10482.

Villareal, T.A., Pilskaln, C.H., Montoya, J.P., Dennett, M., 2014. Upward nitrate transport by phytoplankton in oceanic waters: balancing nutrient budgets in oligotrophic seas. PeerJ 2, e302. https://doi.org/10.7717/peerj.302.

Wolk, F., Yamazaki, H., Seuront, L., Lueck, R.G., 2002. A new free-fall profiler for measuring biophysical microstructure. J. Atmos. Ocean. Technol. 19, 780-793. https:// doi.org/10.1175/1520-0426(2002) 019<0780:ANFFPF > 2.0.CO;2.

Wyatt, T., 2014. Margalef's mandala and phytoplankton bloom strategies. Deep. Res. Part II Top. Stud. Oceanogr. 101, 32-49. https://doi.org/10.1016/j.dsr2.2012.12.006.

Zapata, M., Rodríguez, F., Garrido, J.L., 2000. Separation of chlorophylls and carotenoids from marine phytoplankton: A new HPLC method using a reversed phase C8 column and pyridine-containing mobile phases. Mar. Ecol. Prog. Ser. 195, 29-45. https://doi. org/10.3354/meps195029. 